\title{
An overview of the Amazonian Aerosol Characterization Experiment 2008 (AMAZE-08)
}

\author{
S. T. Martin ${ }^{1}$, M. O. Andreae ${ }^{2}$, D. Althausen ${ }^{3}$, P. Artaxo ${ }^{4}$, H. Baars ${ }^{3}$, S. Borrmann ${ }^{2}$, Q. Chen ${ }^{1}$, D. K. Farmer ${ }^{5}$, \\ A. Guenther ${ }^{6}$, S. S. Gunthe ${ }^{2}$, J. L. Jimenez ${ }^{5}$, T. Karl $^{6}$, K. Longo ${ }^{7}$, A. Manzi ${ }^{8}$, T. Müller ${ }^{3}$, T. Pauliquevis ${ }^{9}{ }^{*}$, \\ M. D. Petters ${ }^{10}$, A. J. Prenni ${ }^{11}$, U. Pöschl' ${ }^{2}$, L. V. Rizzo ${ }^{4}$, J. Schneider ${ }^{2}$, J. N. Smith ${ }^{6}$, E. Swietlicki ${ }^{12}$, J. Tota ${ }^{8}$, \\ J. Wang ${ }^{13}$, A. Wiedensohler ${ }^{3}$, and S. R. Zorn ${ }^{2}$ \\ ${ }^{1}$ School of Engineering and Applied Sciences and Department of Earth and Planetary Sciences, Harvard University, \\ Cambridge, Massachusetts, USA \\ ${ }^{2}$ Max Planck Institute for Chemistry, Mainz, Germany \\ ${ }^{3}$ Leibniz Institute for Tropospheric Research, Leipzig, Germany \\ ${ }^{4}$ Institute of Physics, University of São Paulo, Brazil \\ ${ }^{5}$ Department of Chemistry and Biochemistry and Cooperative Institute for Research in the Environmental Sciences, \\ University of Colorado, Boulder, Colorado, USA \\ ${ }^{6}$ NCAR Earth System Laboratory, National Center for Atmospheric Research, Boulder, Colorado, USA \\ ${ }^{7}$ Center of Weather Forecast and Climatic Studies (CPTEC-INPE), Cachoeira Paulista, São Paulo, Brazil \\ ${ }^{8}$ National Institute of Amazonian Research (INPA), Manaus, Brazil \\ ${ }^{9}$ Institute of Astronomy, Geophysics and Atmospheric Science, University of São Paulo, Brazil \\ ${ }^{10}$ Department of Marine, Earth, and Atmospheric Sciences, North Carolina State University, Raleigh, North Carolina, USA \\ ${ }^{11}$ Department of Atmospheric Science, Colorado State University, Fort Collins, Colorado, USA \\ ${ }^{12}$ Department of Physics, Lund University, Lund, Sweden \\ ${ }^{13}$ Department of Earth and Atmospheric Sciences, University of Nebraska, Lincoln, Nebraska, USA \\ *now at: Earth and Natural Sciences Department, Federal University of Sao Paulo at Diadema, Diadema, Brazil
}

Received: 4 June 2010 - Published in Atmos. Chem. Phys. Discuss.: 30 July 2010

Revised: 2 November 2010 - Accepted: 17 November 2010 - Published: 2 December 2010

\begin{abstract}
The Amazon Basin provides an excellent environment for studying the sources, transformations, and properties of natural aerosol particles and the resulting links between biological processes and climate. With this framework in mind, the Amazonian Aerosol Characterization Experiment (AMAZE-08), carried out from 7 February to 14 March 2008 during the wet season in the central Amazon Basin, sought to understand the formation, transformations, and cloud-forming properties of fine- and coarse-mode biogenic aerosol particles, especially as related to their effects on cloud activation and regional climate. Special foci included (1) the production mechanisms of secondary organic components at a pristine continental site, including the factors regulating their temporal variability, and (2) predicting and understanding the cloud-forming properties of biogenic particles at such a site. In this overview paper, the field site and the instrumentation employed during the campaign are introduced. Observations and findings are reported, including the
\end{abstract}

Correspondence to: S. T. Martin

(scot_martin@harvard.edu) large-scale context for the campaign, especially as provided by satellite observations. New findings presented include: (i) a particle number-diameter distribution from $10 \mathrm{~nm}$ to $10 \mu \mathrm{m}$ that is representative of the pristine tropical rain forest and recommended for model use; (ii) the absence of substantial quantities of primary biological particles in the submicron mode as evidenced by mass spectral characterization; (iii) the large-scale production of secondary organic material; (iv) insights into the chemical and physical properties of the particles as revealed by thermodenuder-induced changes in the particle number-diameter distributions and mass spectra; and (v) comparisons of ground-based predictions and satellite-based observations of hydrometeor phase in clouds. A main finding of AMAZE-08 is the dominance of secondary organic material as particle components. The results presented here provide mechanistic insight and quantitative parameters that can serve to increase the accuracy of models of the formation, transformations, and cloud-forming properties of biogenic natural aerosol particles, especially as related to their effects on cloud activation and regional climate.

Published by Copernicus Publications on behalf of the European Geosciences Union. 


\section{Introduction}

The Amazon Basin is a highly favorable environment for studying the sources, transformations, and properties of biogenic aerosol particles (Andreae et al., 2002; Martin et al., 2010). In contrast, advection in the widely polluted northern midlatitudes of North America, Europe, and Asia mixes together anthropogenic and natural components of particles. Amazonian studies can potentially isolate natural processes and, in doing so, can provide a baseline understanding against which anthropogenic effects on atmospheric aerosol sources and properties can be understood (Andreae, 2007). This kind of understanding is relevant not only to the Northern Hemisphere of today but also to the Amazon Basin of the future under several possible development scenarios. Focused on these possibilities, the Amazonian Aerosol Characterization Experiment (AMAZE-08) was carried out in the wet season of 2008.

A summary of the sources of Amazonian aerosol particles and important influences on their atmospheric lifetimes and aging processes can be found in the review of Martin et al. (2010). A short introduction is provided herein, as follows. In-Basin natural processes include emissions both of primary biological aerosol particles (PBAPs) and of gaseous sulfur, nitrogen, and carbon species from the ecosystem, oxidation of the gaseous species not just in the atmospheric gas phase but also in cloud water to produce low-volatility particle-phase products (i.e., secondary particle components), and removal of gases and particles by wet and dry deposition. The strongest anthropogenic influence inside the Basin is biomass burning, which is especially prevalent in the dry season and in the southern part of the Basin during that time (i.e., outside of both the temporal and geographic scope of AMAZE-08). Influences originating out of the Basin and advecting into it include marine particles from the Atlantic Ocean, dust and biomass burning in Africa, and gaseous species from both regions that can be converted within the Basin into secondary components of particles. The particles from African sources arrive in the Basin sporadically as events and are more common in the austral summer than winter. The biomass-burning emissions from Africa can be regarded largely as an anthropogenic component.

The scientific objective of AMAZE-08 was to understand the formation, transformations, and cloud-forming properties of fine- and coarse-mode biogenic natural aerosol particles, especially as related to their effects on cloud activation and regional climate. Special foci included (1) the production mechanisms of secondary organic components at a pristine continental site, including the factors regulating their temporal variability, and (2) predicting and understanding the cloud-forming properties of biogenic particles at such a site. These foci can be broadly described as an investigation on the link between biological processes and climate, as mediated by atmospheric chemistry (Barth et al., 2005; Keller et al., 2009).
The worldwide production mechanisms of secondary organic components from the oxidation of volatile organic compounds (VOCs) have received considerable attention in the literature during the past few years (Chung and Seinfeld, 2002; Tsigaridis and Kanakidou, 2003; Tsigaridis et al., 2005; Henze and Seinfeld, 2006; Tsigaridis and Kanakidou, 2007; Heald et al., 2008). There has been significant uncertainty regarding the contribution by primary organic emissions, compared to in situ photochemical production of secondary organic aerosol (SOA), to the mass concentration of organic particle material in urban areas, ranging from $80 \%$ primary in the study of Pandis et al. (1992) to 35\% primary in the studies of Zhang et al. (2005) and Volkamer et al. (2006, 2007). Attribution between anthropogenic and biogenic secondary organic material remains uncertain (Millet et al., 2006). Volkamer et al. (2006) and de Gouw and Jimenez (2009) emphasize that previous conclusions from global models may vastly underestimate the anthropogenic contribution. There are missing sources of SOA production in polluted anthropogenic regions (de Gouw et al., 2005; Takegawa et al., 2006; Volkamer et al., 2006) and also in the free troposphere (Heald et al., 2005), as implied by observations of excess organic mass concentrations compared to best-model predictions. Carbon-14 dating of secondary organic material in areas heavily influenced by anthropogenic sources implies a high biogenic fraction and thus an important role of biogenic species (Klinedinst and Currie, 1999; Szidat et al., 2004). In contrast, models for these conditions predict that the quantities of SOA material produced from biogenic sources should be small. The implication of the discrepancy between observations and models is that synergistic biogenic-anthropogenic interactions exist that are not well understood at present (de Gouw et al., 2005). These several observations, among others, have highlighted the need for a more thorough understanding of SOA production (Goldstein and Galbally, 2007; Kroll and Seinfeld, 2008; Carlton et al., 2009; Hallquist et al., 2009).

The Amazon in the wet season represents a pristine environment having nearly pure biogenic aerosol particles (Artaxo et al., 1990; Gerab et al., 1998; Andreae et al., 2002; Claeys et al., 2004; Andreae, 2007; Martin et al., 2010), making it an ideal laboratory to isolate natural SOA production and thereby provide a baseline understanding against which to measure anthropogenic influences. The Amazon Basin is the region of highest VOC emissions globally (Guenther et al., 1995; Kesselmeier et al., 2009; Vrekoussis et al., 2009). Moreover, the high solar flux and large biogenic emissions lead to a large source of $\mathrm{OH}$ radicals (Lelieveld et al., 2008). As a result, SOA production in the gas phase is initiated dominantly by $\mathrm{OH}$ radicals. Ozone concentrations (5 to $20 \mathrm{ppb}$ ) are relatively low in Amazonia, and $\mathrm{O}_{3}$-initiated SOA production is therefore less important than that of the $\mathrm{OH}$ pathways. Nitrate radical concentrations are low in Amazonia and are believed to contribute negligibly to SOA production. SOA production also occurs in cloud water (Lim et al., 2005; 
Carlton et al., 2008, 2009; Ervens et al., 2008). The factors influencing the relative importance of gas- and aqueousphase pathways for SOA production remain to be well delineated, especially for the environmental parameters prevalent in the Amazon Basin.

Predicting and understanding the cloud-forming properties of atmospheric particles, especially for particles having high organic fractions, is essential for accurate predictions of convection dynamics, precipitation, and energy fluxes and their integration with climate at all scales. The pristine conditions of the wet season of the Amazon Basin, in which the organic volume fractions of particles approach $90 \%$ (Fuzzi et al., 2007), represent an excellent opportunity for the development of this understanding. Both the development of warm clouds by activation of cloud condensation nuclei (CCN) and of cold clouds by activation of ice nuclei (IN) are important. Prior to AMAZE-08, ice nuclei had never before been studied in Amazonia, and studies of the IN properties of organic particles in other parts of the globe have been hampered by the difficulty of disentangling the contribution of organic material from that of sulfate and dust, which have been mixed together. For this reason, measurements in the Amazon in the wet season are particularly important for the isolation of the IN properties of organic particles.

Roberts et al. (2001, 2002, 2003), Rissler et al. (2004), and Mircea et al. (2005) measured CCN number concentrations in the Amazon Basin during the wet season. Those studies, however, did not investigate the dependence of $\mathrm{CCN}$ activity on the particle size, including their possible temporal variation. The construction of accurate microphysical models of cloud formation, precipitation, and energy fluxes is not possible without information on the size-dependent $\mathrm{CCN}$ activity. More advanced models linked to variable chemistry also cannot be developed without measurements on how particle chemistry potentially changes during the day and with size (i.e., from the condensation of secondary organic products as well as possible heterogeneous aging reactions such as by $\mathrm{OH}$ radical).

In this overview paper of AMAZE-08 (7 February to 14 March 2008), the field site and the instrumentation employed during the campaign are introduced (Sect. 2). Observations and findings are reported, including the large-scale context for the campaign (especially as provided by satellite observations) (Sect. 3), a summary of AMAZE-08 publications available to date (Sect. 3.1), and five sections with new results not published elsewhere (Sects. 3.2.1-3.2.5). The topics of these sections are selected to provide a perspective on the results from AMAZE-08 regarding the formation, the transformations, and the cloud-forming properties of biogenic natural aerosol particles, especially as related to their effects on cloud activation and regional climate.

\section{Measurements}

The principal measurement site of AMAZE-08 was tower TT34 $\left(02^{\circ} 35.657^{\prime} \mathrm{S}, 060^{\circ} 12.557^{\prime} \mathrm{W}, 110 \mathrm{~m}\right.$ a.s.l.) (Fig. 1$)$. It was located in the central Amazon Basin, $60 \mathrm{~km} \mathrm{NNW}$ of downtown Manaus and $40 \mathrm{~km}$ from the metropolis margins. The site, accessed by a 34-km unpaved road, was within a pristine terra firme rainforest in the Reserva Biológica do Cuieiras and managed by the Instituto Nacional de Pesquisas da Amazonia (INPA) and the Large-Scale Biosphere-Atmosphere Experiment in Amazonia (LBA). The base of tower TT34 was on a ridge, and the scale of hill-valley relief near the tower was ca. $50 \mathrm{~m}$. The forest canopy height near the tower varied between 30 and $35 \mathrm{~m}$. Housing for the researchers and a $60 \mathrm{~kW}$ diesel generator for power supply were located $0.33 \mathrm{~km}$ and $0.72 \mathrm{~km}$ downwind of TT34, respectively. The generator was separated from TT34 by a 50-m deep valley, with the researcher housing at the bottom of the valley.

Climatological and meteorological information for this region of the Amazon Basin is provided by Andreae et al. (2002) and Araujo et al. (2002). The rainfall during AMAZE-08 was consistent with the typical monthly values of the wet season (Fig. S1). The meteorological statistics recorded at the top of the tower during AMAZE- 08 were 23 to $27^{\circ} \mathrm{C}$ (quartiles of distribution) and 80 to $99 \% \mathrm{RH}$ in the daytime; the nighttime statistics were 22 to $24^{\circ} \mathrm{C}$ and 96 to $100 \% \mathrm{RH}$. The quartiles of pressure were 9.9 to $10 \times 10^{5} \mathrm{~Pa}$. The recommendation was to normalize AMAZE-08 data sets to standard temperature and pressure $\left(0^{\circ} \mathrm{C}, 10^{5} \mathrm{~Pa}\right.$, dry air $)$. Normalization facilitated quantitative comparisons among AMAZE-08 data sets, as well as with data sets of earlier and future measurement campaigns.

In addition to TT34, there were three auxiliary sites. Tower K34 $\left(2^{\circ} 36.545^{\prime} \mathrm{S}, 60^{\circ} 12.558^{\prime} \mathrm{W}\right.$, and $130 \mathrm{~m}$ a.s.l.; $1.6 \mathrm{~km}$ from TT34; $54 \mathrm{~m}$ height) housed several instruments directly at its top level (Ahlm et al., 2009). Site $\mathrm{K} 23\left(2^{\circ} 38.307^{\prime} \mathrm{S}, 60^{\circ} 9.430^{\prime} \mathrm{W}\right.$, and $108 \mathrm{~m}$ a.s. 1 ; $7.56 \mathrm{~km}$ from TT34) was used for tethered balloon soundings up to $800 \mathrm{~m}$. A light detection and ranging instrument (LIDAR) and one site of the Aerosol Robotic Network (AERONET) were located $19.1 \mathrm{~km}$ from TT34 at the Silvicultura site $\left(02^{\circ} 35.913^{\prime} \mathrm{S}, 060^{\circ} 02.240^{\prime} \mathrm{W}\right.$ ) (Althausen et al., 2009; Ansmann et al., 2009).

At TT34, air was entrained into three inlets fixed at $38.75 \mathrm{~m}$ to the top of the tower. The air was brought by sampling lines to a ground-level container $\left(2.2 \times 5.9 \times 2.5 \mathrm{~m}^{3}\right)$ (Fig. S2). The inlet for gases consisted of an inverted funnel having an insect screen across it. The inlet for turbulent-flow aerosol sampling was a screen-covered open tube that was placed very close to a sonic anemometer and positioned in the direction of predominant wind flow. An inlet with an aerodynamic cutoff nominally of $\mathrm{PM}_{10}$ but actually of $\mathrm{PM}_{7}$ for our flow conditions was used for laminar-flow aerosol sampling. The sampling lines running from these inlets to 

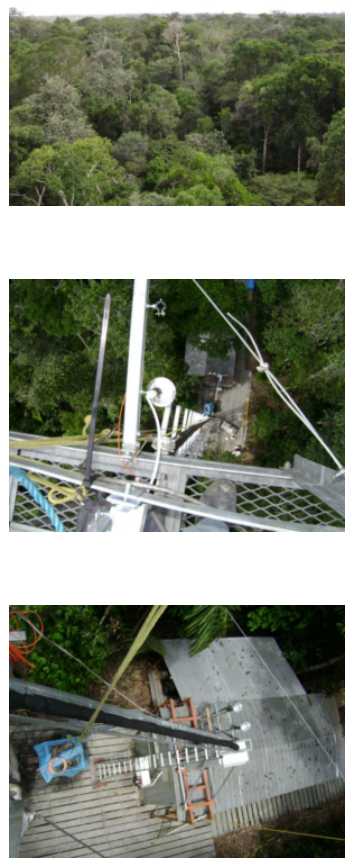

Container

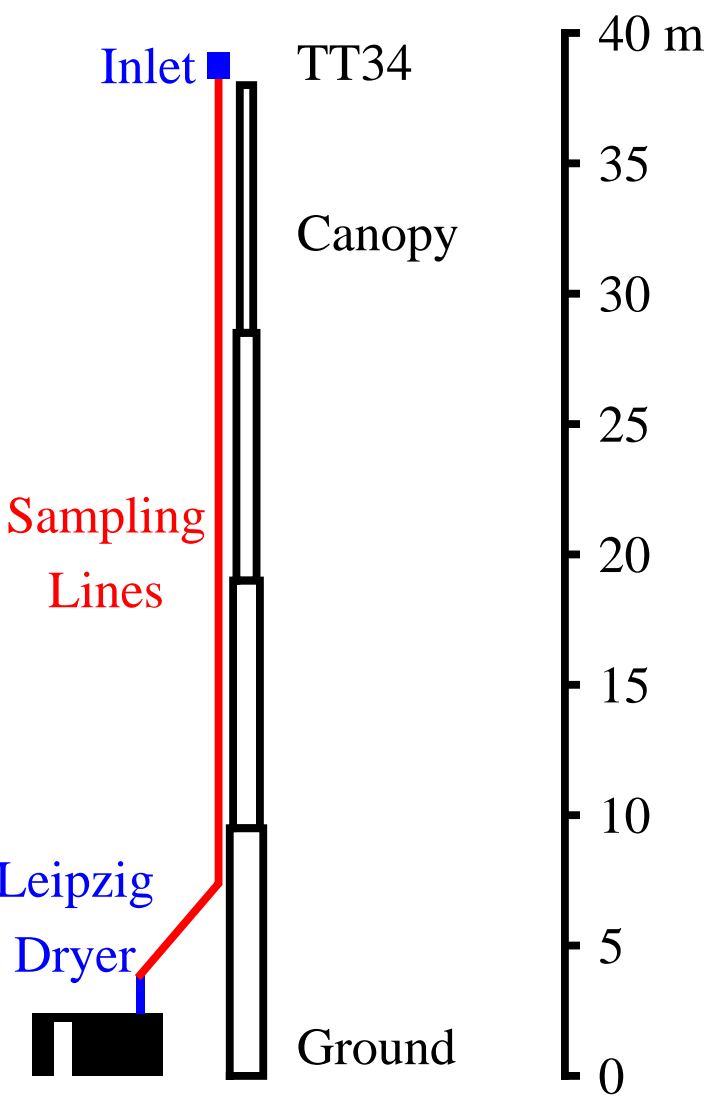

Fig. 1. Diagram of four-section telescopic tower (TT34), showing positions of inlet, canopy, sampling lines, dryer, and instrument container. Inset photos are shown larger in Fig. S2.

the container included a 6.4-mm (1/4" OD) Teflon line for gas sampling, a $12.7-\mathrm{mm}\left(1 / 2^{\prime \prime} \mathrm{OD} ; 10.9 \mathrm{~mm}\right.$ ID) stainless steel line for turbulent-flow aerosol sampling, and a $19-\mathrm{mm}$ (3/4" OD; $17.3 \mathrm{~mm}$ ID) stainless steel line for laminar-flow aerosol sampling. From the sampling height to the container, the three lines were wrapped together and encased by sections of heating tape and insulation. Feedback control was used to maintain the temperature at $30 \pm 1^{\circ} \mathrm{C}$ to avoid water condensation in the sampling lines.

Most of the particle instrumentation in the container sampled from the laminar line (Table 1). For the dimensions and flow of the laminar sampling line, the Reynolds number varied from 1200 to 2000 during the period of measurements. The calculated diffusional and gravitational deposition losses for a particle of dynamic shape factor of 1 and a density of $1000 \mathrm{~kg} \mathrm{~m}^{-3}$ indicate $50 \%$ transmission cutoffs of $4 \mathrm{~nm}$ and $10.5 \mu \mathrm{m}$ through the sampling lines, with increased transmission between those sizes (www.seas.harvard.edu/ AerosolCalculator). A Reynolds number of 2000 approaches the turbulent regime, and in this case the calculated $50 \%$ transmission cutoffs shift to $13 \mathrm{~nm}$ and $3.5 \mu \mathrm{m}$ for losses by gravitational settling, diffusional impaction, and inertial deposition. The upper limit of the aerodynamic cutoff was therefore calculated to range from 5 to $7 \mu \mathrm{m}$ for the range of flow rates employed during AMAZE-08. Therefore, the lower and upper limits of transmission of the inlet-samplingline assembly were calculated as $4 \mathrm{~nm}$ to $7 \mu \mathrm{m}$, respectively, for the condition of laminar flow. Comparison between this calculated size-transmission window and a typical measured number-diameter distribution suggests that there was minimal loss of particle number concentration during transit in the sampling line running from the inlet at the top of the tower to the instruments in the container below. This expectation was confirmed for the laminar line by the good agreement between the particle number concentrations recorded using condensation particle counters (CPCs) inside the TT34 container and those recorded by a CPC on the top of tower K34 (Fig. 2). A self-regenerating automatic dryer was placed on the top of the container and intercepted the laminar sampling line prior to entrance into the container. The dryer consisted of two diffusion dryers in parallel, one drying the aerosol flow while the other was bypassed and regenerated by dry air (Tuch et al., 2009). The flow was switched from one dryer to the other at a threshold of $40 \% \mathrm{RH}$. By this sequence, the RH was kept between 20 and $40 \%$ when measured by an in-line sensor (Fig. 3). The cabinet housing 


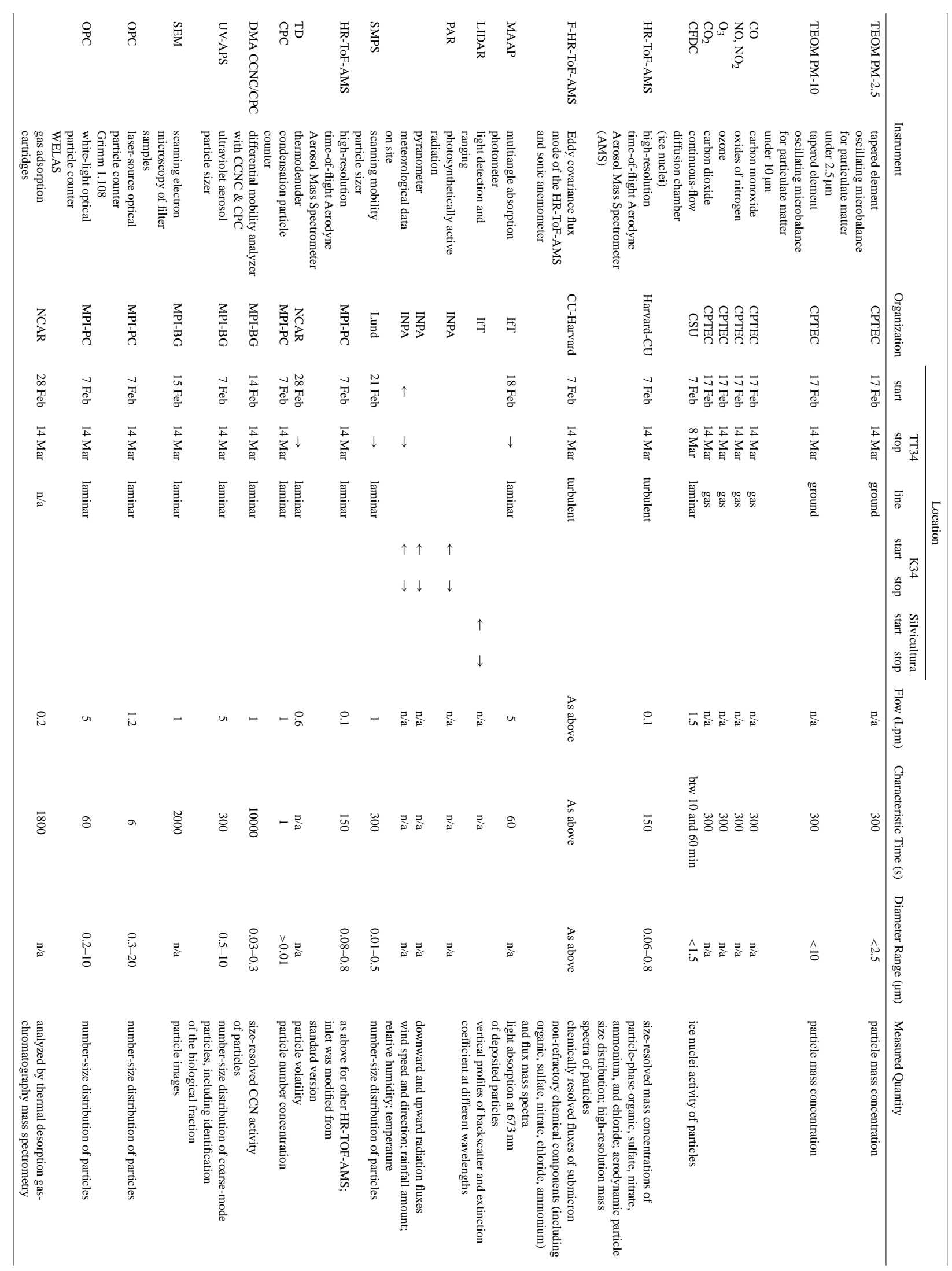




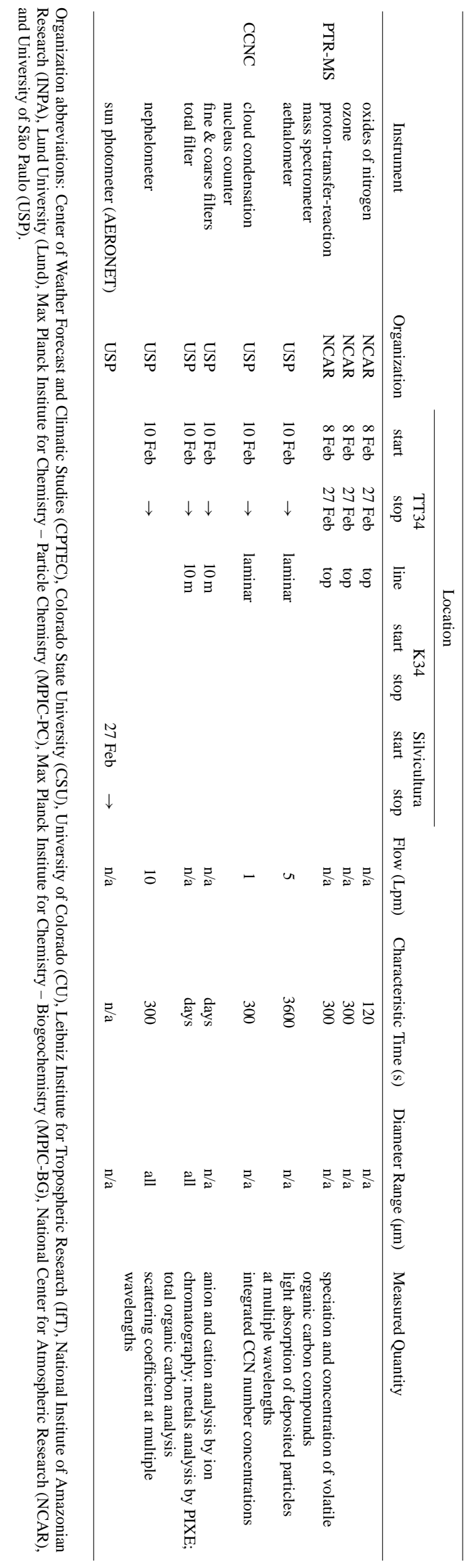

$\stackrel{0}{0}$
$\stackrel{0}{0}$
$\stackrel{0}{0}$
$\stackrel{0}{0}$
$\stackrel{0}{0}$
$\stackrel{0}{0}$
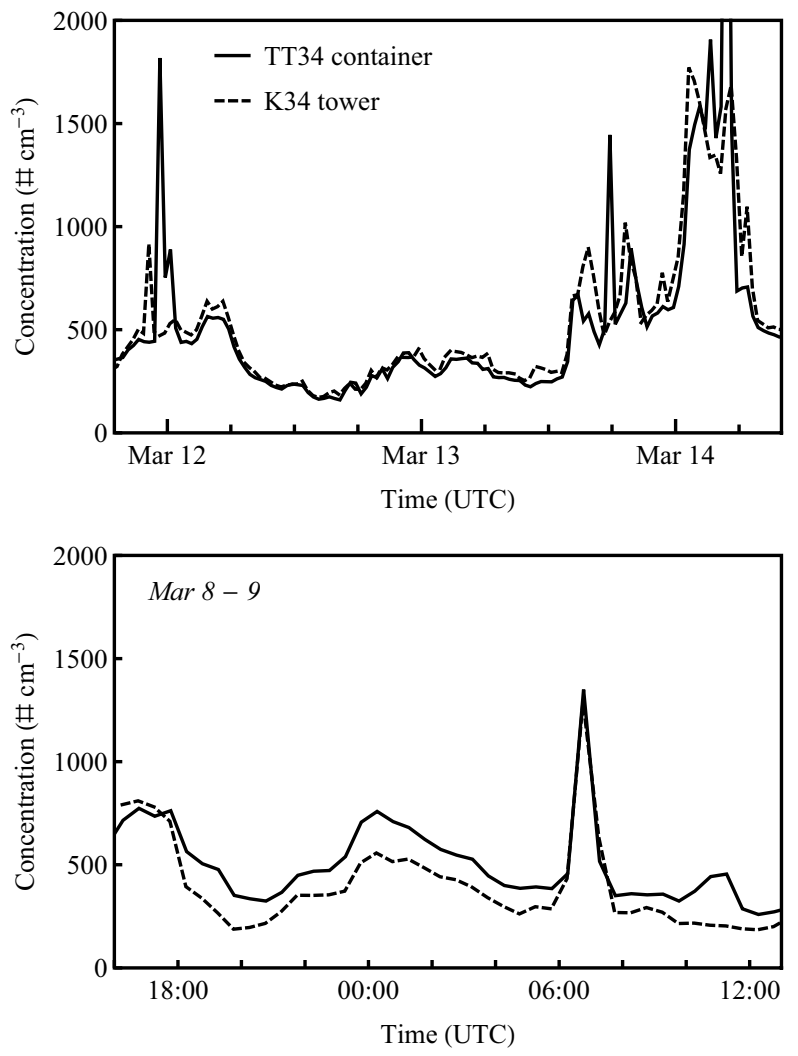

Fig. 2. Particle number concentrations recorded inside the container at the bottom of tower TT34 and contemporaneously at the top of tower K34, which was located $1.6 \mathrm{~km}$ from TT34. (The excursions above $500 \mathrm{~cm}^{-3}$ represented as abrupt spikes are tagged as pollution events in Fig. S4. These spikes are believed to arise when the omnipresent regional plume from Manaus, which is generally westward, veers to the north and intersects the AMAZE-08 site. The similar magnitude of the spikes at TT34 and K34 supports that the inlet and sampling on both towers did not introduce bias into the measurements of the total particle number concentration).

the dryer on top of the container was consistently several degrees warmer than inside the container. The RH therefore increased by up to $20 \%$ in the distribution lines inside the container prior to sampling by instruments. The set point of the air-conditioning inside the container was $23^{\circ} \mathrm{C}$, although the temperature was warmer by $3^{\circ} \mathrm{C}$ or more near some of the instruments.

The turbulent sampling line was dried to 40 to $70 \%$ relative humidity by use of a Nafion RH-exchange tube that intercepted the sampling line on the roof of the container just prior to entrance. The partial pressure of water in the outer flow around the Nafion material (with the aerosol in the inner flow) was reduced by expansion through a critical orifice, with underpressure provided by a vacuum pump. The turbulent sampling line was operated at a Reynolds number of 5000 to 10000 , and the 


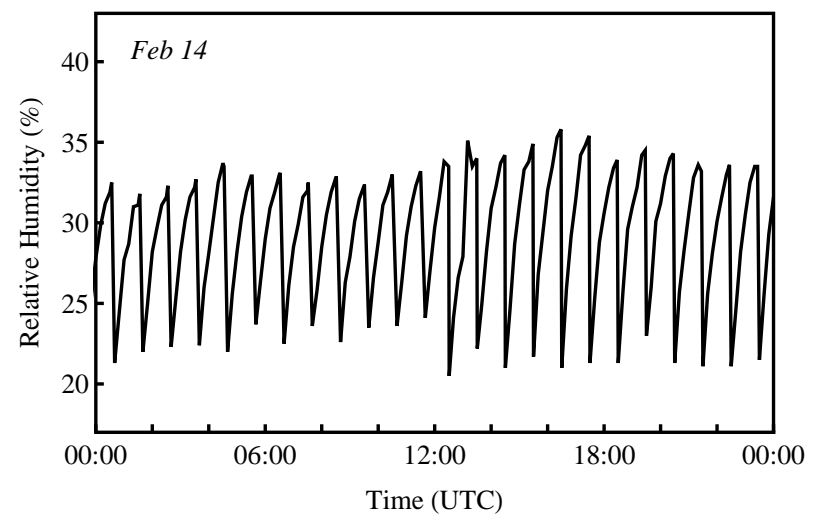

Fig. 3. Relative humidity in the laminar-flow aerosol sampling line using the dryer described by Tuch et al. (2009). The dryer consists of two diffusion dryers (silica gel), and the aerosol flow is diverted into one dryer while the second one is regenerated. When the threshold RH for regeneration is reached, the aerosol flow is diverted to that dryer. The method of regeneration is a dry-air flow obtained from a compressor.

corresponding diffusional, gravitational, and inertial deposition losses suggest $50 \%$ transmission cutoffs of $17 \mathrm{~nm}$ and $3.1 \mu \mathrm{m}$, with $100 \%$ transmission between these cutpoints. The line for gas sampling entered the container without interception. For some gas measurements, additional sampling lines were temporarily placed at various heights along the tower (Karl et al., 2009).

The instruments housed inside the container and the sampling line used by each instrument are listed in Table 1 . The subset of instruments related to Sect. 3.2 "New Results" include: a condensation particle counter (CPC, TSI model 3010); a scanning mobility particle sizer (Lund SMPS described by Svenningsson et al., 2008); an optical particle counter (OPC, Grimm model 1.108); an ultraviolet aerodynamic particle sizer (UV-APS, TSI model 3314; Huffman et al., 2010); the LIDAR instrument discussed previously; two high-resolution time-of-flight Aerodyne Aerosol Mass Spectrometers (HR-ToF-AMS) (DeCarlo et al., 2006), one belonging to Harvard University Environmental Chemistry Laboratory and equipped with a standard inlet (Liu et al., 2007) and the other belonging to the Max Plank Institute - Particle Chemistry (MPI-PC) group and equipped with a novel inlet shifted to favor larger diameter particles; a thermodenuder as described in Wehner et al. (2002); and a continuous-flow diffusion chamber for measurements of ice nuclei (Rogers et al., 2001).

\section{Observations and findings}

Back-trajectory analyses and satellite observations covering the trajectory paths during the period of AMAZE-08 provide large-scale information concerning both the sources of
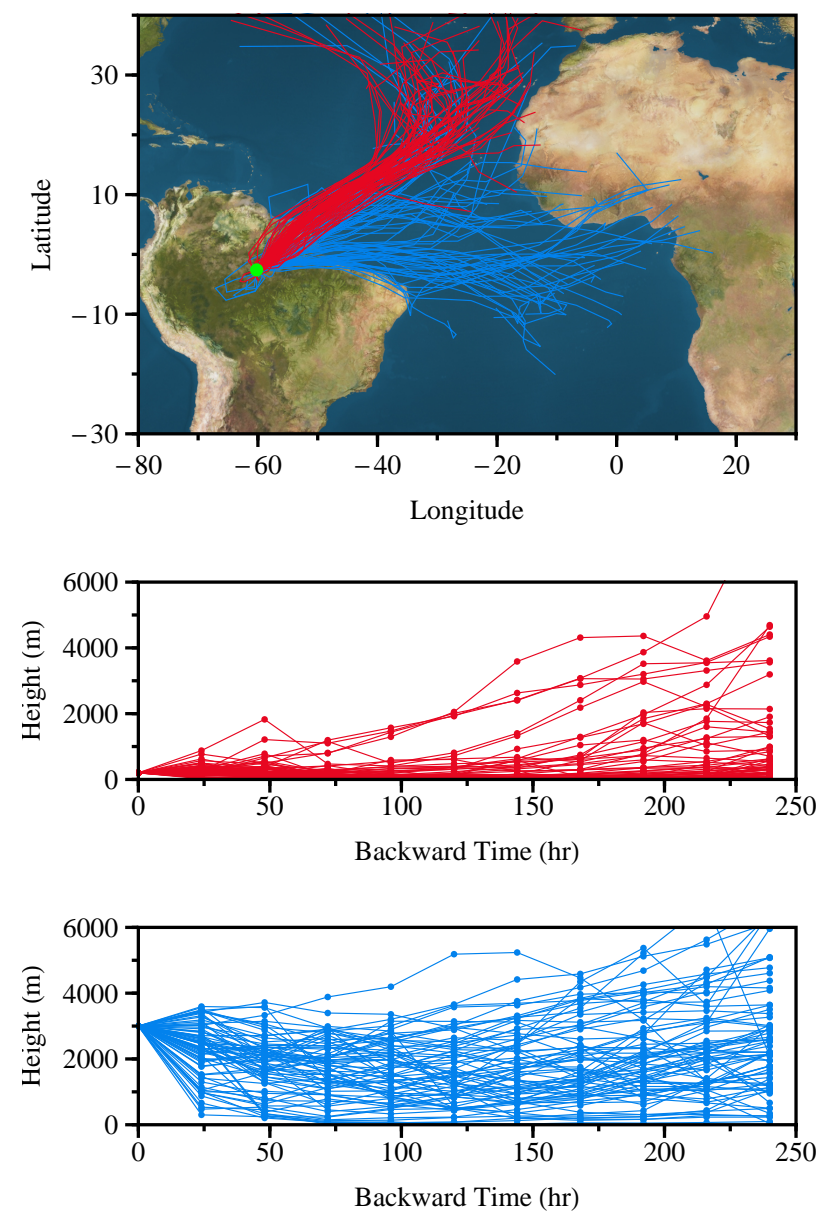

Fig. 4. Ten-day HYSPLIT backtrajectories at $200 \mathrm{~m}$ (red) and $3000 \mathrm{~m}$ (blue) during AMAZE-08. Each point along a trajectory represents a 12-h step. The green point marks the location of tower TT34.

particles and the transformations of particle components. The backtrajectories arriving at the site at 200 and $3000 \mathrm{~m}$ above ground level are shown every $12 \mathrm{~h}$ from 7 February to 14 March 2008 in Fig. 4 (Draxler and Hess, 1998) (see Fig. S3 for 500, 1000, 2000, and $4000 \mathrm{~m}$ ). The figure shows that the synoptic-scale trade winds came predominantly and consistently from the northeast, travelling across the Atlantic Ocean and then over $1600 \mathrm{~km}$ of nearly pristine forest before arrival at the research site. The low-altitude flow was from the northeast, changing to easterlies at mid-altitude. Local wind measurements at the top of the research tower confirmed that the daytime winds were dominantly from the north and northeast (Fig. 5). At nighttime, the winds stagnated at times and could come from any direction.

The trajectories represented in Fig. 4, suggesting smooth trajectories of air parcels, are a HYSPLIT product that uses a Lagrangian framework and omits treatment of vertical mixing. Treating atmospheric transport over a ten-day period 
(a) Daytime

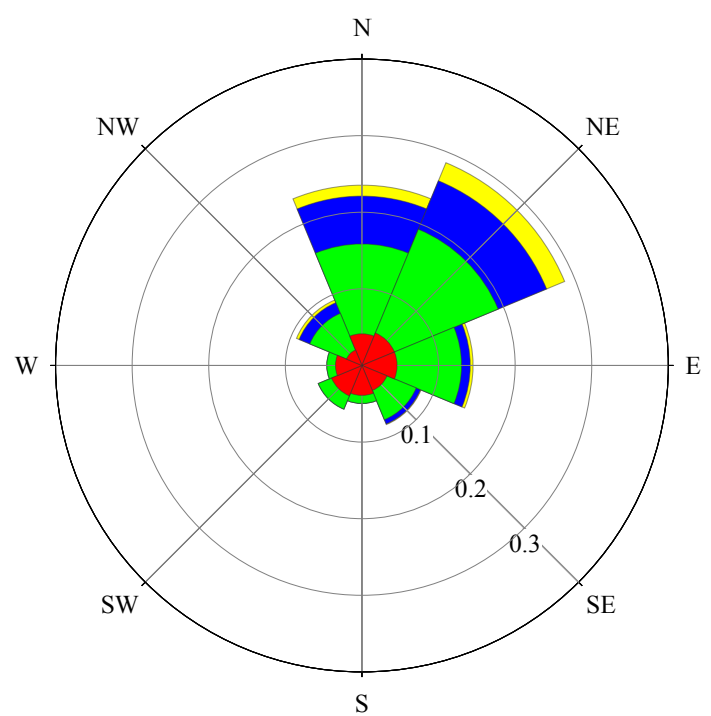

(b) Nighttime

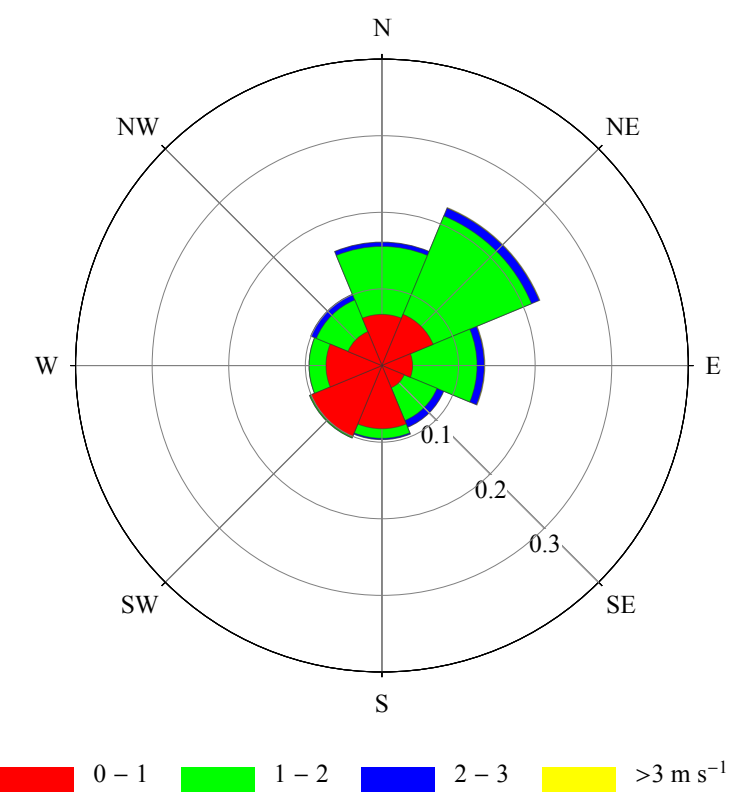

Fig. 5. Daytime and nighttime wind roses measured at the top of tower TT34 during AMAZE-08. The concentric circles represent the fractional frequency of winds from different sector directions. Within each sector, the color coding of radial distance indicates the relative frequencies of the wind speeds.

with a Lagrangian parcel model is a strong simplification of the complexities of atmospheric movement. Vertical exchange and cloud processing take place along the path of transport and modify concentrations and properties of airmass tracers. Nevertheless, the consistency of the trajectories from day to day and the weak vertical shear in the lower 3-5 $\mathrm{km}$ of trade winds both suggest that the representation in Fig. 4 is a reasonable first-order description of airmass transport. In the particular situation of AMAZE-08, there is strong observational support for the validity of this approach. Ben-Ami et al. (2010) documented the transport of dust and smoke across the Atlantic Ocean along the path suggested by the trajectories in Fig. 4 by using a combination of remote sensing and surface observations.

An implication of the backtrajectories shown in Fig. 4 is that, in addition to in-Basin sources and transformations, the particles of the Amazon Basin during AMAZE-08 were also affected at times by soil dust transport from northern Africa and biomass burning in equatorial Africa. Satellite observations support this possibility and further indicate that the long-range transport of material from Africa to the research site was episodic during AMAZE-08 (Ben-Ami et al., 2010). Comparison of the ten-day backtrajectories and satellitebased MODIS fire counts (Figs. 4 and 6) suggests that advection of biomass-burning products from Africa may have occurred. LIDAR measurements record a large plume of dust and smoke over Cape Verde on 3 February 2008 that arrives one week later at the research site in the Amazon Basin (Ansmann et al., 2009). Particle optical depth recorded by MODIS on the AQUA satellite during the period of AMAZE08 is also supportive of the possibility of long-range transport of biomass-burning products (Fig. 7). In contrast, an influence of regional biomass burning appears less plausible because of the absence of fires along the in-Basin trajectories (Fig. 8). The absence of markers of fresh biomass burning both in the particle-phase mass spectra (e.g., elevated signal intensity at $m / z, 60$ and 73) and in the gas-phase mass spectra (e.g., the benzene:acetonitrile ratio) further confirms this conclusion (Chen et al., 2009; Karl et al., 2009).

Elevated African dust emissions occurred several times during the period of AMAZE-08, as apparent in the MODIS observations of Fig. 7. Based on the backtrajectories during these times, a portion of these emissions may have reached the research site approximately one week later. Simulations using the global chemical transport model "GEOS-Chem" for the AMAZE-08 time period, as well as measurements of fine-mode dust concentrations at the research site, suggest several significant events $\left(>0.5 \mu \mathrm{g} \mathrm{m}^{-3}\right)$ of African dust transport to the research site compared to background concentrations $\left(<0.2 \mu \mathrm{g} \mathrm{m}^{-3}\right)$ (Prenni et al., 2009a), in general agreement with earlier reports of episodic dust intrusion (Prospero et al., 1981; Andreae et al., 1990; Artaxo et al., 1990; Swap et al., 1992; Formenti et al., 2001).

In addition to the influence of synoptic-scale upwind sources, the vertical structure of the local atmosphere must be considered for the interpretation of nighttime compared to daytime measurements at TT34. Nighttime and daytime differences in the height and the stability of the planetary boundary layer largely bifurcate the scientific context of the measurements at TT34 during these two periods. At 

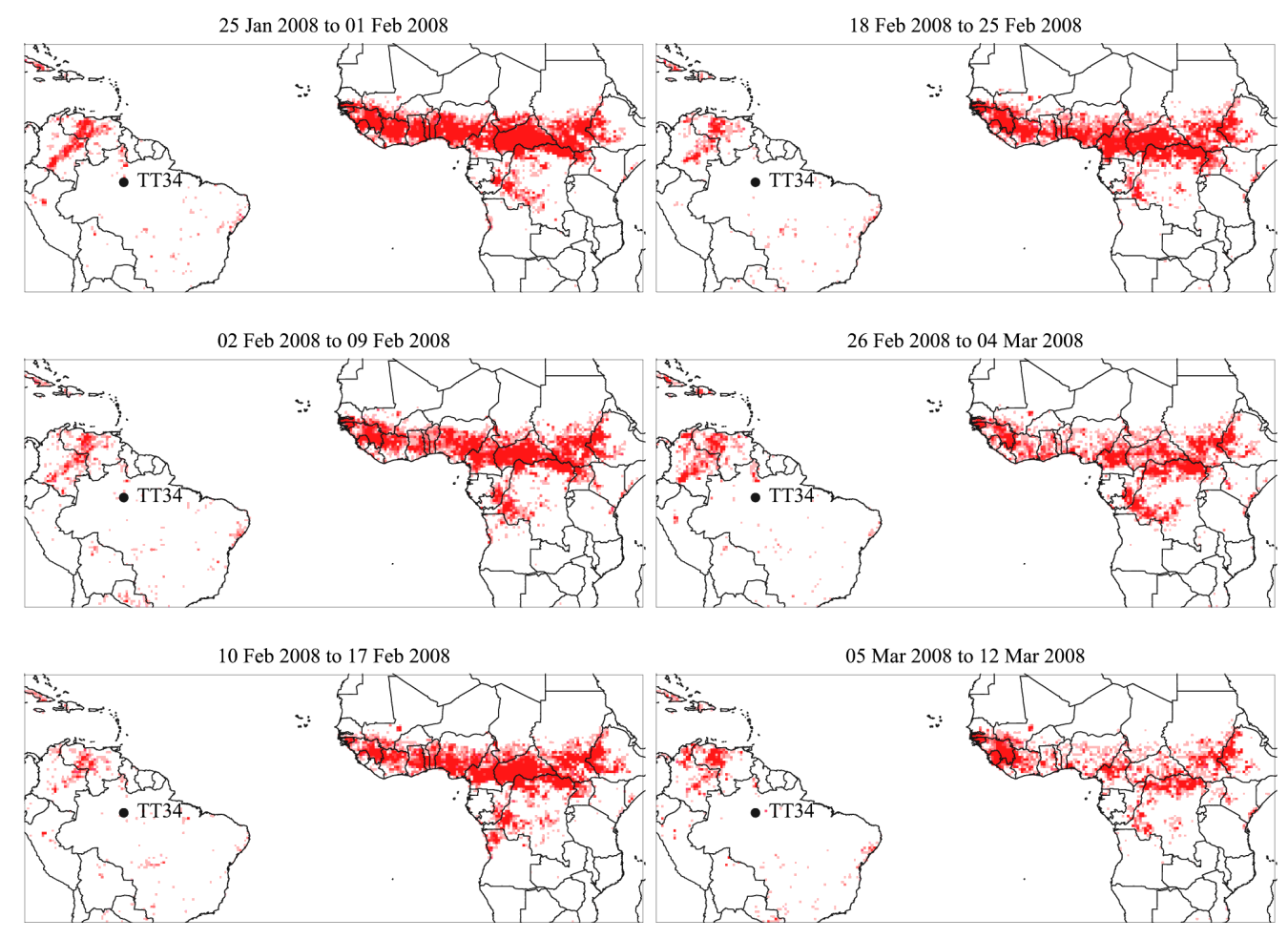

Fig. 6. Gridded statistical summaries of fires over Africa and South America. Panels are prepared using the eight-day composites of the Climate Modeling Grid (CMG) Fire Products of the MODIS Collection-5 Active Fire Product (Giglio et al., 2006). Red is scaled from 0 to 25 pixel fire counts, with corrections for cloud cover. Some pixels have more than 25 fire pixels (e.g., maximum value for scenes shown is 1000 pixel fire counts).

nighttime, katabatic (i.e., hill-valley) flows are important (Araujo et al., 2002). The nighttime measurements therefore had a microscale fetch, in contrast to the mesoscale reach of the daytime measurements. As a result, the nighttime measurements at TT34 were influenced by local activities, such as nighttime ecosystem emissions. Although there is considerable interest in the nighttime activities of tropical forests (Graham et al., 2003a; Guyon et al., 2003a; Gilbert, 2005), the focus of AMAZE-08 was on mesoscale processes.

The development of the boundary-layer structure at night was driven by the formation of a nocturnal planetary boundary layer (PBL) that had a height comparable to the local topographical relief, which was 50 to $100 \mathrm{~m}$ around TT34. In this region of the Amazon Basin, the thickness of the convective PBL typically varies from $100-200 \mathrm{~m}$ at night to 1 to $2 \mathrm{~km}$ when fully developed in the mid afternoon (Martin et al., 1988; Garstang et al., 1990; Fisch et al., 2004). Several balloon soundings made during AMAZE-08 were consistent with these values (Figs. 9 and 10), with a PBL-top height near 700 to $800 \mathrm{~m}$ by local noon.

The development of the planetary boundary layer, which can be observed by LIDAR measurements, is shown in the left panel of Fig. 11 for 13 March 2008. The black line shows the PBL-top height that was derived by the method of Baars et al. (2008). In the morning (12:00 UTC is 08:00 LT), the PBL-top height was $200 \mathrm{~m}$. From 13:00 to 14:00, the PBLtop height increased from 400 to $800 \mathrm{~m}$. By 14:30, cloud formation occurred. The figure also shows that residual layers present at 500 and $800 \mathrm{~m}$ in the morning became entrained by local noon in the PBL. Another layer of particles is apparent at approximately $2000 \mathrm{~m}$, possibly the result of long-range transport or a cloud residual layer, among other possibilities.

The height-resolved backscatter coefficients averaged across two different time periods are shown in the right panel of Fig. 11. In the first period (12:30-13:10 UTC), a shallow convective boundary layer and an overlying residual layer from the day before are revealed in the profile of the backscatter coefficient. A sharp, steep gradient occurs at the top of the PBL. A lofted particle layer is located between $1300 \mathrm{~m}$ and $2400 \mathrm{~m}$ at that time. An hour later (14:0714:20 UTC), the vertical structure of the backscatter coefficient evolves significantly, showing the growth of the PBL up to $800 \mathrm{~m}$ and the mixing of the lofted residual layer into the PBL. The second lofted layer has descended, having its lower limit at about $1100 \mathrm{~m}$.

Some of the measurement periods at TT34 were affected by local pollution, especially at night. The nocturnal hillvalley flow, in combination with the shallow boundary layer, 
25 Jan 2008 to 01 Feb 2008

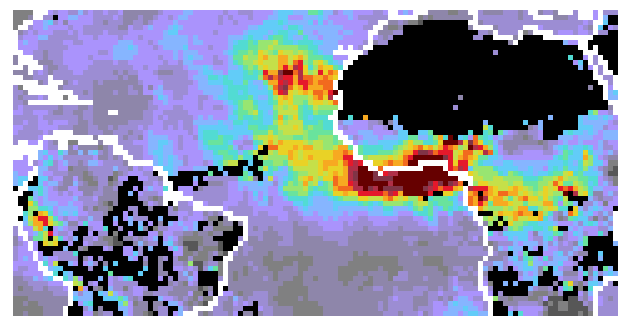

02 Feb 2008 to 09 Feb 2008

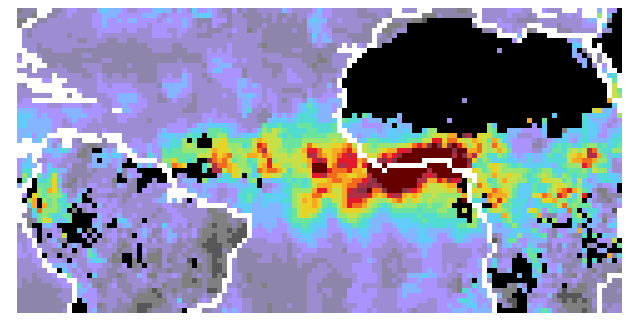

10 Feb 2008 to 17 Feb 2008

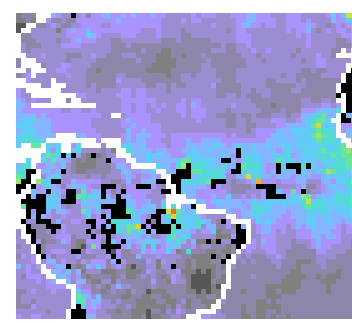

18 Feb 2008 to 25 Feb 2008

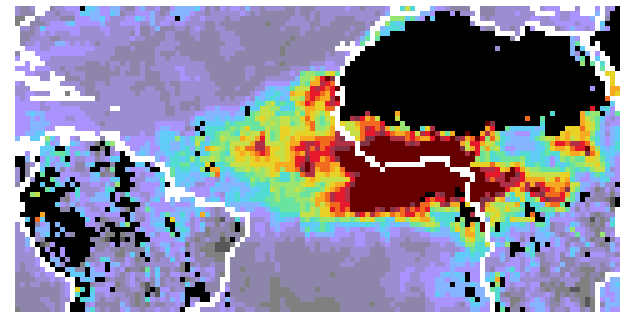

26 Feb 2008 to 04 Mar 2008

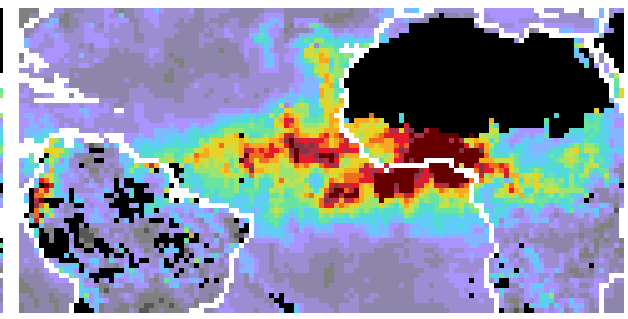

05 Mar 2008 to 12 Mar 2008

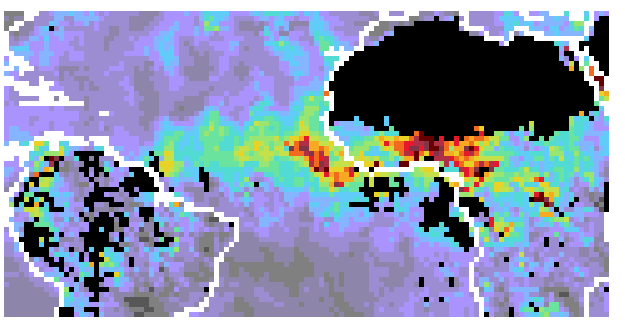

0

0.2

0.4

$0.6>0.8$

Fig. 7. Particle optical depth observed by the MODIS instrument on the AQUA satellite (Levy et al., 2007; Remer et al., 2008). Shown are the level-3 eight-day composites of Collection 5.

led at times to a circulation of generator exhaust to the research station, and these events (which were evident in the data sets of multiple instruments; Fig. S4) were tagged and logged into a community file accessed by AMAZE-08 researchers. Intersection of the generator plume with the research station was abrupt (i.e., total particle concentrations could increase above $1000 \mathrm{~cm}^{-3}$ for $15 \mathrm{~min}$, drop back to $300-400 \mathrm{~cm}^{-3}$ for $15 \mathrm{~min}$, and then jump again above $1000 \mathrm{~cm}^{-3}$; Fig. S4). The abrupt behavior reflected the narrow horizontal extent and the shifting nature of the generator plume. The duration of one of these events was typically several hours. Other local pollution (both at day and night) arrived at times from metropolitan Manaus. This pollution was apparent in multiple data sets (Fig. S4), was continuous, lasted for time periods of up to a day or more (the longest period was $38 \mathrm{~h}$ ), and corresponded to local winds from the direction of Manaus. The greater duration of the Manaus plume compared to that of the generator is explained by their respective horizontal scales. Unless stated specifically otherwise, the data associated with the periods of local pollution (constituting $24 \%$ of the measurement period) were excluded from AMAZE-08 analyses. Besides these tagged periods, the site was free of local anthropogenic influences.

\subsection{Published results}

Several recent publications describe findings from AMAZE08. Karl et al. (2009) employed measurements of isoprene photo-oxidation products to infer missing chemistry in standard models of atmospheric chemistry, complementing other recent theoretical (Peeters et al., 2009), laboratory (Paulot et al., 2009), and field (Kuhn et al., 2007; Lelieveld et al., 2008) results on this topic. These results suggested more rapid oxidation of biogenic emissions than presently implemented in chemical transport models and, correspondingly, enhanced formation of oxygenated products that might favorably partition to the particle phase (Guyon et al., 2003a, 

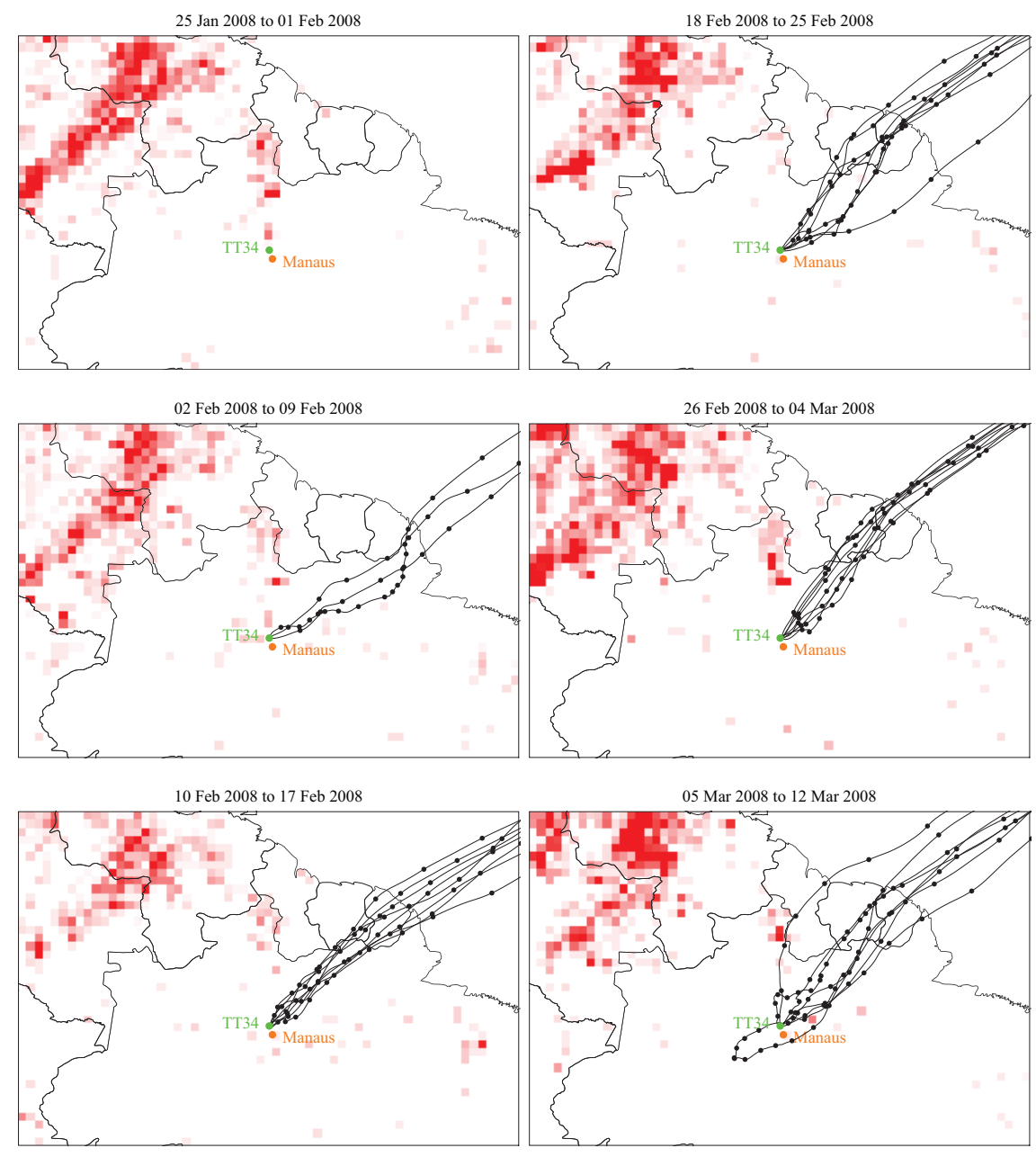

Fig. 8. Gridded statistical summaries of fires in the central and northern Amazon Basin. Red is scaled from 0 to 25 pixel fire counts; the maximum value for the shown scenes is 200. Further information is provided in the caption to Fig. 6. The HYPSLIT backtrajectories at $200 \mathrm{~m}$ that terminate at TT34 during the eight-day period are shown beginning 7 February 2008 (i.e., corresponding to the start of AMAZE-08 measurements). Markers represent steps of $12 \mathrm{~h}$. The trajectory that loops back around from Manaus is for 7 March 2008.

b, 2004). Consistent with these results, Chen et al. (2009) demonstrated that the organic material of submicron particles in the Amazon Basin can be dominated by the in-Basin production of secondary organic aerosol. Chen et al. (2009) employed an HR-ToF-AMS, and the mass spectra showed that the non-refractory components of the submicron particles consisted of 80 to $90 \%$ organic material. The balance appeared as acidic sulfate, approximately $\mathrm{NH}_{4} \mathrm{HSO}_{4}$; a caveat is that some fraction may also have been organosulfate species, which have a similar fragmentation pattern in the AMS as inorganic sulfate and so the two species cannot be fully discriminated by this instrument (Farmer et al., 2010). Gunthe et al. (2009) conducted size-resolved measurements of the cloud-condensation-nuclei $(\mathrm{CCN})$ activity of submicron particles and, using the size-resolved chemical measurements of Chen et al. (2009), obtained the value of the effective hygroscopicity parameter of the organic component. The value obtained by Gunthe et al. (2009) was similar to that of chamber-generated secondary organic material (King et al., 2007, 2009, 2010). Pauliquevis et al. (2010) used the findings of Gunthe et al. (2009) to initialize a modeling case study of the condensational growth of cloud droplets in the pristine atmosphere of the Amazon Basin. The model results suggested that the secondary organic material present in the particles influences the cloud droplet number concentration, at least for low to medium updraft velocities. The implication is that the biogenic emissions of organic compounds from Amazonian vegetation (including photo-oxidation of volatile organic compounds) influence cloud microphysics in the Basin. 


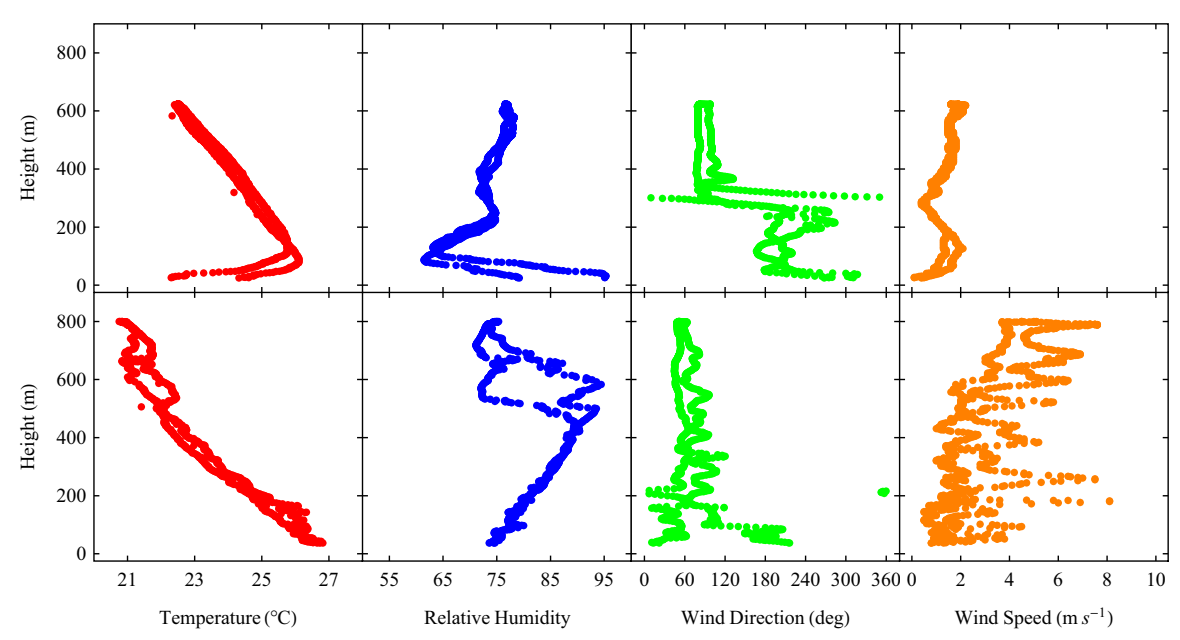

Fig. 9. Vertical profiles of temperature, relative humidity, wind direction, and wind speed from balloon soundings at site K23. Top row: night, 04:18 through 04:52 UTC of 14 March 2008. Bottom row: day, 16:29 through 16:59 UTC of 15 March 2008. Local time was -4h with reference to coordinated universal time (UTC), and this region of the Amazon does not practice daylight savings time.

The aforementioned AMAZE-08 publications collectively had a focus on secondary organic material. Other recent AMAZE-08 publications have reported on other particle sources and properties. Ben-Ami et al. (2010) used satellite observations to directly track for the first time a single plume of African biomass burning and its mixing with Saharan dust from the Bodélé depression over eight days to its arrival into the Amazon Basin. Ansmann et al. (2009) used two LIDAR systems, one situated over Cape Verde and the other at the AMAZE-08 site, to investigate changes in mixing with transport. Dust and biomass-burning particles observed as distinct layers over Cape Verde evolved and mixed into a combined layer by the time of their arrival at the AMAZE08 site. Prenni et al. (2009a) found that natural primary biological particles produced continually within the Amazon Basin were as important as episodic Saharan dust for explaining the time-series variance of the ice nuclei number concentrations. Furthermore, for freezing temperatures warmer than $-25^{\circ} \mathrm{C}$, the biological particles dominated the IN population.

In addition to these studies having a primary focus on AMAZE-08, the recent literature includes several studies that make secondary use of the data in. Andreae (2009) used AMAZE-08 data to investigate correlations between the concentrations of cloud condensation nuclei and particle optical thickness in remote and polluted regions. Several examples of AMAZE-08 data are included in a review article by Martin et al. (2010) concerning the sources and properties of Amazonian aerosol particles. Prenni et al. (2009b) studied heterogeneous ice nucleation by secondary organic materials in the laboratory and presented comparisons to data collected in AMAZE-08. Tuch et al. (2009) selected the AMAZE-08 data as the primary example in a publication describing the design and performance of an automatic regenerating dryer. In a laboratory study of the cloud droplet activation of mixed organic-sulfate particles produced by the photooxidation of isoprene, designed to represent essential aspects of the wetseason Amazon, King et al. (2010) provided a comparison of laboratory results to the observations reported by Gunthe et al. (2009) for the Amazon. Heald et al. (2010) carried out a metastudy of three locations, including the Amazon Basin, as well as laboratory results, to provide a simplified description of the elemental composition of organic particles and related implications for processes of atmospheric aging.

\subsection{New results}

In addition to the reports summarized above that have already appeared in the literature, further major findings concerning Amazonian aerosol particles are summarized herein for the first time. These findings include the number-diameter distribution from $10 \mathrm{~nm}$ to $10 \mu \mathrm{m}$ (Sect. 3.2.1), mass spectral characterization to test for primary biological particles (Sect. 3.2.2), evidence of large-scale production of secondary organic material (Sect. 3.2.3), insights into the chemical and physical properties of the aerosol particles based on thermodenuder analyses (Sect. 3.2.4), and the phase of hydrometeors in clouds (Sect. 3.2.5).

\subsubsection{Number-diameter distribution}

As a reference figure for the Amazon Basin in the pristine wet season, a composite number-diameter distribution from $10 \mathrm{~nm}$ to $10 \mu \mathrm{m}$ is shown in the top panel of Fig. 12. The distribution is dominated by submicron particles: $99 \%$ of all particles have mobility diameters smaller than $300 \mathrm{~nm}$. The supermicron range constitutes $0.1 \%$ of the particle number 
Table 2. Mean and quartiles of (a) CPC number concentration $( \pm 10 \%)$, (b) AMS-measured organic mass concentration ( $\pm 30 \%)$, (c) AMSmeasured sulfate mass concentration $( \pm 30 \%)$, (d) AMS-measured ammonium mass concentration $( \pm 30 \%)$, (e) AMS-measured nitrate mass concentration $( \pm 30 \%)$, (f) organic mass fraction calculated as $b$ divided by the sum of $b$ to $e$, (g) AMS-measured oxygen-to-carbon (O:C) elemental ratios of the organic particle-phase material, and (h) AMS-measured hydrogen-to-carbon (O:C) elemental ratios of the organic particle-phase material. Data are screened to remove time periods affected by local pollution ("all data" column). Data are also shown segregated into morning, afternoon, and night.

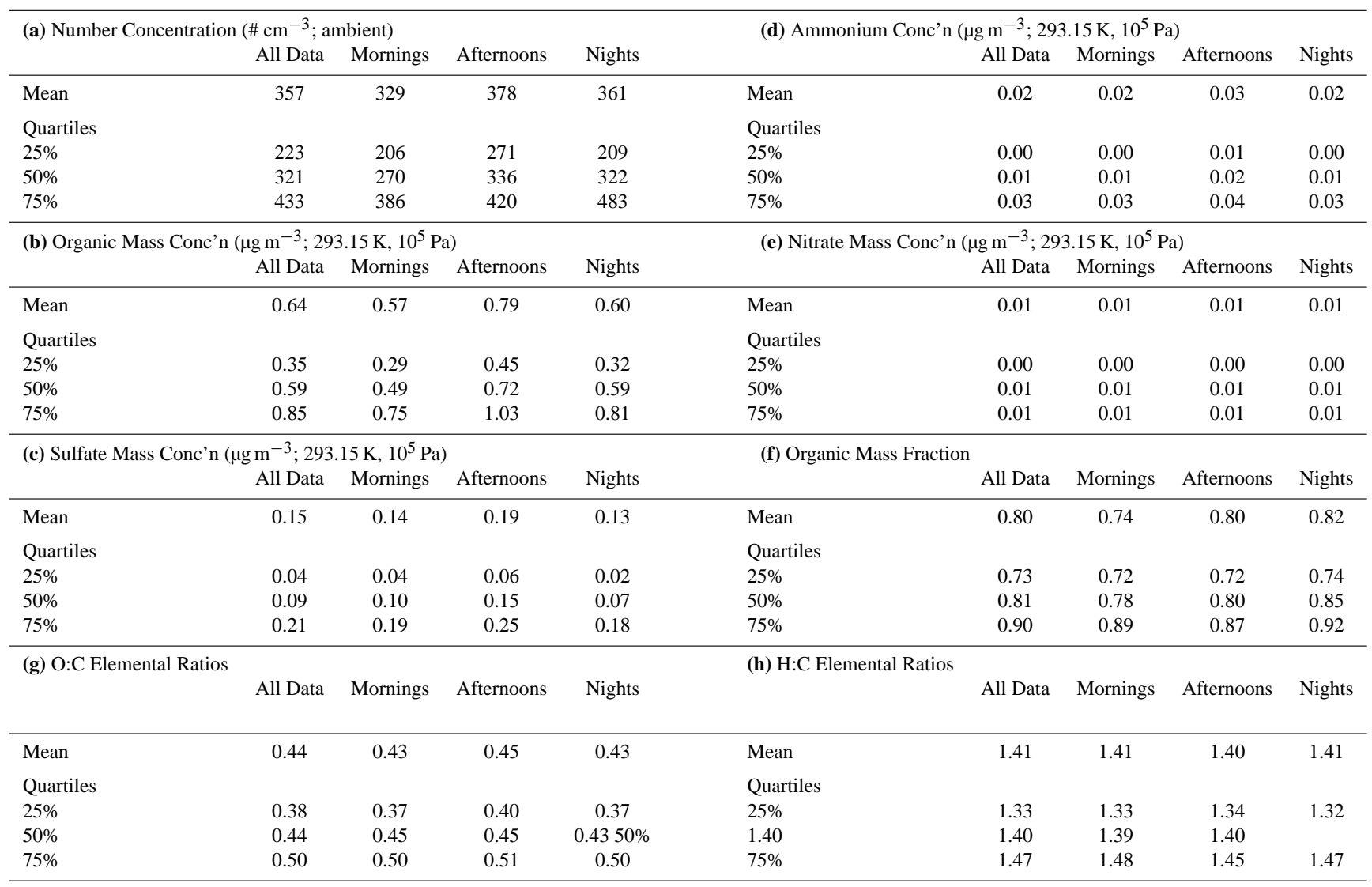

concentration. The quartiles of total particle number concentration measured by the condensation particle counter were 223, 321, and $433 \mathrm{~cm}^{-3}$ during AMAZE-08 (Table 2).

The number-diameter distribution shown in Fig. 12 was constructed by combining measurements from a scanning mobility particle sizer, an optical particle counter, and an ultraviolet aerodynamic particle sizer. These methods rely on different physical measurement principles and therefore represent different types of diameters (viz. mobility, optical, and aerodynamic diameters, respectively). These different diameters have not been adjusted. The abscissa is thus simply termed "diameter" in Fig. 12. The figure shows that the agreement between the instruments for overlapping portions of the diameter domain is good, at least up to about $4 \mu \mathrm{m}$.

The distributions for these larger particles are based on the UV-APS and OPC measurements. The figure shows that the OPC observes the presence of particles with sizes larger than $4 \mu \mathrm{m}$ that the UV-APS does not indicate. The explana- tion may be that the aerodynamic cutoff of the inlet-sampling system was between 5 and $7 \mu \mathrm{m}$, consistent with the size distributions observed by the UV-APS. The implication is that the particles detected up to $10 \mu \mathrm{m}$ with respect to optical diameter (which represents the efficacy of light scattering compared to the calibration particles of polystyrene latex spheres) have smaller aerodynamic diameters. For instance, these results can be explained by non-spherical particles having a dynamic shape factor above unity, particles having a density less than that of water, or a refractive index greater than that of PSL material. For the typical particle types observed in the Amazon Basin, a dynamic shape factor larger than unity is perhaps the most plausible explanation (e.g., primary biological particles such as fungal spores).

The size distribution shown in Fig. 12 represents a time period (6 to 13 March 2008) chosen as having exceptionally low mass concentrations: (1) the submicron organic and sulfate particle mean mass concentrations (adjusted to $0^{\circ} \mathrm{C}$ and 


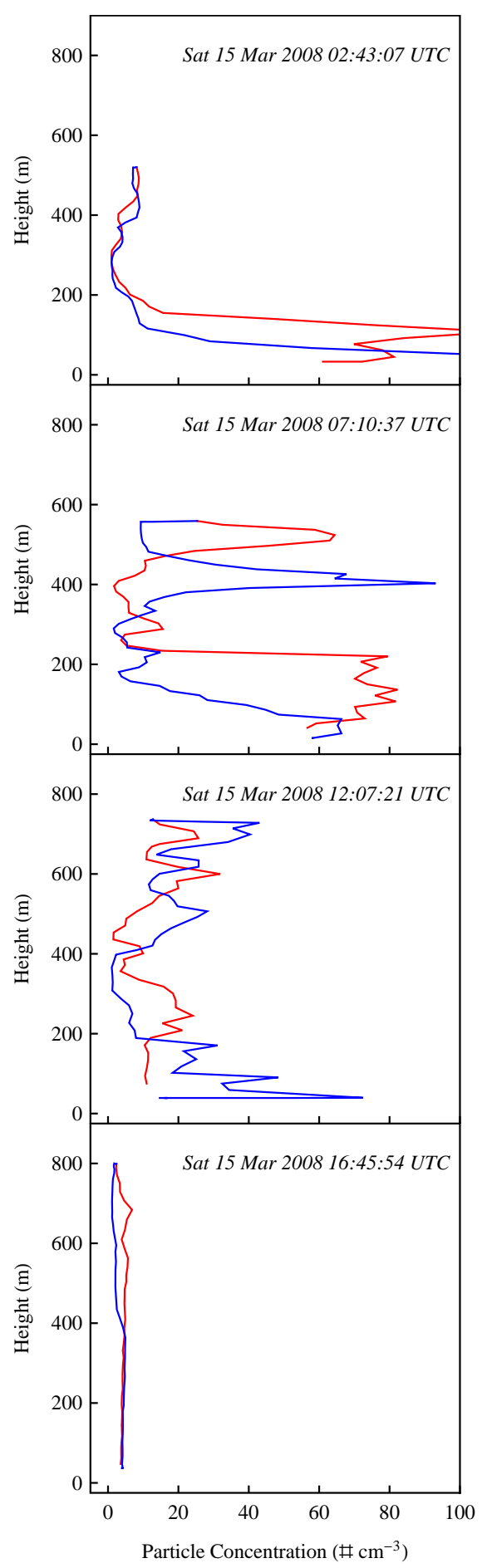

Fig. 10. Vertical profiles of total particle concentration from a fourchannel optical particle counter $(0.3 \mu \mathrm{m}, 0.5 \mu \mathrm{m}, 1 \mu \mathrm{m}$, and $5 \mu \mathrm{m})$ employed in balloon soundings at site K23 on 15 March 2008. Red and blue lines show ascending and descending portions of the soundings.
$10^{5} \mathrm{~Pa}$ ) were 0.58 and $0.05 \mu \mathrm{g} \mathrm{m}^{-3}$, respectively, during this period, compared to 0.64 and $0.15 \mu \mathrm{g} \mathrm{m}^{-3}$ for AMAZE-08 as a whole; (2) the median total number concentration was $360 \mathrm{~cm}^{-3}$; and (3) integration of the vertical profile of the 532-nm LIDAR extinction coefficient (cf. the right panel of Fig. 11) for 13 March yielded a particle optical thickness of 0.03 . The lower concentrations are believed to correspond to time periods having minimal out-of-Basin influences (Chen et al., 2009), and the plot in Fig. 12 is therefore believed to represent a steady-state dynamic balance characteristic of the Amazon Basin. As implied by the tight 90-percentile distribution bands and the robust mode positions in Fig. 12, the number-diameter distribution is resilient and steady. Strong rain events tested the resiliency of the distribution: it returned to its steady-state characteristics within 1 to $12 \mathrm{~h}$ after the rain. The rain events were typically localized, and the explanation for that resiliency may be that large-scale mixing homogenized the Basin and erased the effects of localized precipitation cells after a short time period.

The middle panels of Fig. 12 show the surface and volume distributions calculated from the number distribution of the top panel. As typical for unpolluted locations worldwide, the larger part of the volume distribution occurs in the coarse mode. Atypically, however, the surface distribution has strong sub- and supermicron contributions in the Amazon Basin, indicating the importance of both modes to light scattering in the Basin (Guyon et al., 2003a, b, 2004). The shaded regions of Fig. 12 represent the 10- and 90-percentiles of the calculated distributions; they do not represent uncertainty. The uncertainty (not shown) increases considerably with diameter in the conversion from a number-diameter distribution to surface-diameter (as diameter-squared) and volume-diameter (as diameter-cubed).

Parameters of a two-mode lognormal distribution fit to approximately describe the data shown in Fig. 12 are given in Table 3. As a consistency check, the parameters for the surface and volume distributions satisfy the Hatch-Choate relationships to the number distribution (Hinds, 1999). The bottom panel of Fig. 12 shows the $\log _{10}$ residuals between the measurements and the parameterization. Across the full size range of $20 \mathrm{~nm}$ to $3 \mu \mathrm{m}$, the median residual (i.e., the heavy line) of the parameterization is within $50 \%$ (i.e., $\left.\Delta \log _{10}<0.2\right)$ of the measured median. The shaded regions represent the 10- and 90-percentiles of the residual of the values calculated by the parameterization compared to the range of measurements. The figures shows that the variability of the concentrations in the Amazon Basin (i.e., as represented by the shaded regions) greatly exceeds any artificial error introduced by selection of a two-mode lognormal parameterization (i.e., compared to other more complex options such as three modes or of a power-law distribution). The two-mode parameterization is thus appropriate for use in models as an expected value of the size distribution in the wet season of the Amazon Basin under pristine conditions. 

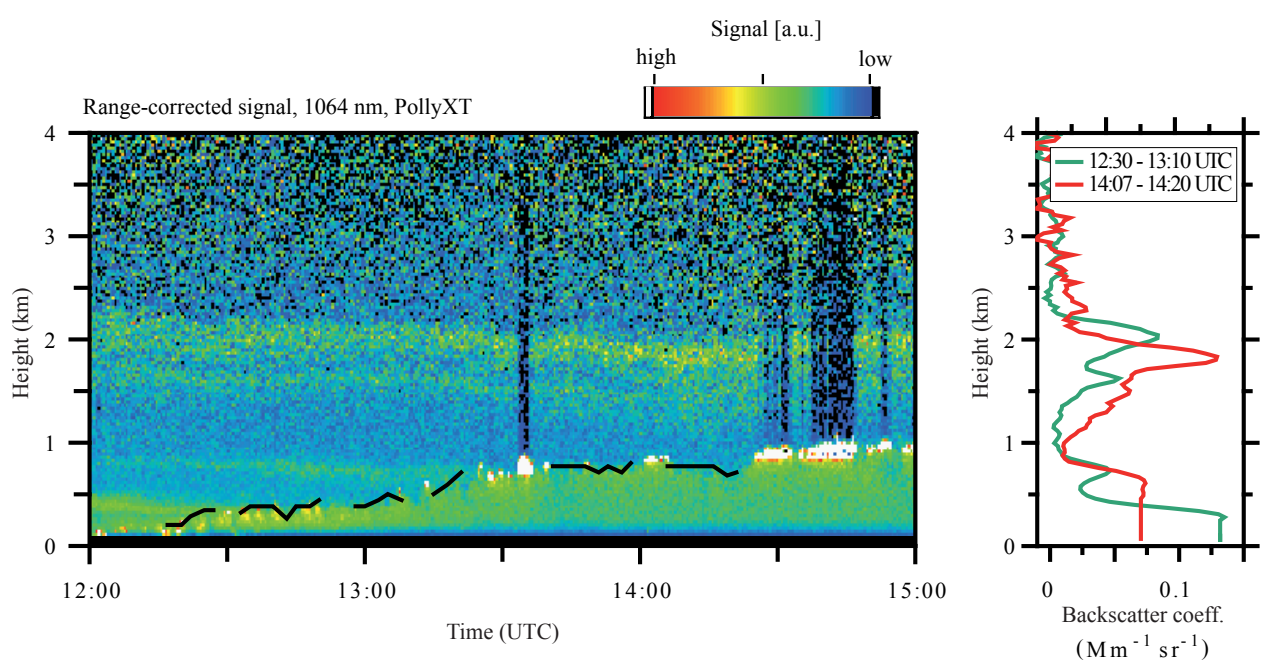

Fig. 11. Vertical profile measured by the PollyXT LIDAR at the Silvicultura site on 13 March 2008. (Left) False-color representation of the time series of the range-corrected signal at $1064 \mathrm{~nm}$. Blue and black represent low backscattering that is characteristic of gases. Green and yellow indicate high backscattering that is characteristic of particles. White shows very high backscattering, which is often caused by clouds. The broken black line represents the top of the planetary boundary layer. (Right) Height-resolved backscatter coefficients averaged across two different time periods.

\subsubsection{Primary biological aerosol particles investigated by mass spectrometry}

A hypothesis often discussed in the literature is that PBAPs contribute significantly to the submicron mass concentration of atmospheric particles, especially in the rain forest (Matthias-Maser and Jaenicke, 1995; Andreae and Crutzen, 1997; Jaenicke, 2005). In partial support of this hypothesis, during the LBA-CLAIRE-2001 campaign in the central Amazon Basin near the site of AMAZE-08, Graham et al. (2003b) detected by chromatography the presence of molecular PBAP tracers in the fine fraction (smaller than $2.5 \mu \mathrm{m}$ ). In an effort to obtain greater quantification of the possible importance of PBAPs in the submicron mode, as part of AMAZE-08 ambient particles were analyzed by online mass spectrometry using the MPI-PC high-resolution time-of-flight Aerodyne Aerosol Mass Spectrometer. The mass spectra collected in AMAZE-08 were compared to those of typical PBAP materials investigated in the laboratory. The fragmentation patterns of amino acids and carbohydrates investigated in the laboratory indicate that there are marker peaks for primary biological material: mass-tocharge $30.0344\left(\mathrm{CH}_{4} \mathrm{~N}^{+}\right), 42.0344\left(\mathrm{C}_{2} \mathrm{H}_{4} \mathrm{~N}^{+}\right)$, and 56.050 $\left(\mathrm{C}_{3} \mathrm{H}_{6} \mathrm{~N}^{+}\right)$for amino acids and $60.0211\left(\mathrm{C}_{2} \mathrm{H}_{4} \mathrm{O}_{2}^{+}\right), 61.0290$ $\left(\mathrm{C}_{2} \mathrm{H}_{5} \mathrm{O}_{2}^{+}\right)$, and $73.0290\left(\mathrm{C}_{3} \mathrm{H}_{5} \mathrm{O}_{2}^{+}\right)$for carbohydrates (Freutel, 2009). A caution is that $\mathrm{m} / \mathrm{z} 60$ and 73 are also used as marker peaks of biomass-burning particles (see above) (Schneider et al., 2006; Alfarra et al., 2007), mainly because of the release of levoglucosan (i.e., an anhydride of the carbohydrate glucose) as a pyrolysis product of cellulose ( $\mathrm{Si}$ moneit et al., 1999; Fraser and Lakshmanan, 2000).
The fractional abundances of the marker peaks measured in the laboratory can be compared with the same quantities in the high-resolution mass spectra recorded for submicron particles during AMAZE-08. This comparison places an upper limit of $7 \%$ on the contribution by amino acids and $5.5 \%$ on that by carbohydrates to the submicron organic mass concentration during AMAZE-08 (Schneider et al., 2010). This limit further provides a reasonable estimate for the total contribution of primary biological material to the submicron organic mass concentration because proteins and carbohydrates constitute approximately two-thirds of the dry mass of a biological cell. These results are consistent with the report of Chen et al. (2009) using the Harvard AMS that there is a dominant presence of biogenic secondary organic components and a minor contribution of PBAP materials in the submicron particle fraction. AMAZE-08 data recorded by the UV-APS show that viable PBAPs occur mainly in the coarse mode, in which they account for $50 \%$ and more of the particle number and mass concentrations (Huffman et al., 2010; Pöschl et al., 2010). These observations contradict the hypothesis that PBAPs contribute significantly to the submicron mass concentration of atmospheric particles (MatthiasMaser and Jaenicke, 1995; Jaenicke, 2005), at least for the wet season of the central Amazon Basin. The results can be reconciled with the earlier observations of Graham et al. (2003b) by consideration of the size regimes of that study $(<2.5 \mu \mathrm{m})$ and the present study (ca. 0.06 to $0.8 \mu \mathrm{m}$ ) (Pöschl et al., 2010). The implication is that PBAP materials strongly contribute to the supermicron particles. 
Table 3. Parameters describing two-mode distributions of number, surface, and volume for the plots of Fig. 12.

\begin{tabular}{lcccccc}
\hline \multicolumn{1}{c}{ Parameter* } & \multicolumn{2}{c}{ Number $N$} & \multicolumn{2}{c}{ Surface $S$} & \multicolumn{2}{c}{ Volume $V$} \\
\hline$i$ & 1 & 2 & 1 & 2 & 1 & 2 \\
$C_{i}$ & $221 \mathrm{~cm}^{-3}$ & $0.34 \mathrm{~cm}^{-3}$ & $9.86 \mu \mathrm{m}^{2} \mathrm{~cm}^{-3}$ & $4.40 \mu \mathrm{m}^{2} \mathrm{~cm}^{-3}$ & $0.36 \mu \mathrm{m}^{3} \mathrm{~cm}^{-3}$ & $1.82 \mu \mathrm{m}^{3} \mathrm{~cm}^{-3}$ \\
$g m d_{i}$ & $0.079 \mu \mathrm{m}$ & $1.56 \mu \mathrm{m}$ & $0.18 \mu \mathrm{m}$ & $2.42 \mu \mathrm{m}$ & $0.27 \mu \mathrm{m}$ & $3.02 \mu \mathrm{m}$ \\
$g s d_{i}$ & 1.90 & 1.60 & 1.90 & 1.60 & 1.90 & 1.60 \\
\hline
\end{tabular}

* For the governing equations: $\frac{d N}{d \log D_{p}}, \frac{d S}{d \log D_{p}}, \frac{d V}{d \log D_{p}}=\sum_{i} \frac{C_{i}}{\sqrt{2 \pi} \log g s d_{i}} \exp \left(-\frac{\left(\log D_{p}-\log g m d_{i}\right)^{2}}{2\left(\log g s d_{i}\right)^{2}}\right)$

\subsubsection{Secondary organic material}

There are six pieces of evidence collected in AMAZE-08 that demonstrate that submicron particles in the Amazon Basin are well described in their properties as secondary organic material. (1) Imaging of collected particles by in-lens scanning electron microscopy reveals liquid organic particles unique to the Amazon Basin, i.e., as compared to continental sites in the anthropogenically influenced Northern Hemisphere (Sinha et al., 2009; Pöschl et al., 2010). (2) Peak positions and intensities are similar between the particle mass spectra collected in AMAZE-08 and those in environmental chambers for SOA particles (introduced in Chen et al., 2009, and further results to be published). (3) Gunthe et al. (2009) report that for AMAZE-08 the average effective hygroscopicity parameter characterizing the size-dependent $\mathrm{CCN}$ activity of pristine rainforest aerosol particles can be accurately predicted using values obtained in the laboratory for secondary organic material. (4) There is an upper limit of $5 \%$ in the fraction of the signal intensity in the particle mass spectrum that can be attributed to primary biological aerosol particles (cf. Sect. 3.2.2 as well as Chen et al., 2009). (5) The average elemental O:C ratio in the Amazon Basin of 0.44 is similar to that measured in environmental chambers for SOA particles and to that expected for two oxygenatom addition to each $\mathrm{C}_{5} \mathrm{H}_{8}$-mer of a biogenic VOC (Chen et al., 2009; Shilling et al., 2009). (6) Thermodenuder treatment at $90^{\circ} \mathrm{C}$ reduces the particle volume concentration by $40 \%$ (i.e., as calculated from changes in the number-diameter distributions measured by an SMPS) and the organic mass concentration measured by the MPI-PC AMS by 55\% (cf. Sect. 3.2.4). In laboratory experiments, a similar reduction in mass concentration occurs for secondary organic material that is comparably heated (Huffman et al., 2009a; Poulain et al., 2009; King et al., 2010).

The picture therefore emerges of the Amazon Basin as a large-scale region for the highly active production of secondary organic aerosol, using the feedstock of plant emissions and high water vapor, combined with the energy from the sun, to sustain high $\mathrm{OH}$ radical concentrations that drive the photo-oxidation of biogenic VOCs. In the submicron mode, an individual particle ranges from nearly a pure liquid of secondary organic material as the most common type of particle (by number) to particles having a solid core that are extensively coated by secondary organic material at volume fractions exceeding 0.5 (Sinha et al., 2009; Pöschl et al., 2010). In the supermicron mode, mineral dust and primary biological aerosol particles having thick liquid coatings of secondary organic material are the norm.

This general view of the Amazon as a highly active region of SOA production is further supported by space-borne sensor observations of the BVOC oxidation product glyoxal (Vrekoussis et al., 2009), by measurements of unexpectedly high OH concentrations (Lelieveld et al., 2008), and by observations indicative of rapid isoprene oxidation (Kuhn et al., 2007; Karl et al., 2009). Work carried out in the Amazon demonstrated the presence of tetrols in collected particles (Claeys et al., 2004), suggesting isoprene as an important source of SOA (Henze and Seinfeld, 2006; Kroll et al., 2006). Chromatographic analysis of material collected on filters during the day compared to the night showed significant differences in molecular composition. Specifically, there were enhanced concentrations in the day of oxygenated organic acids that are indicative of fresh SOA production and/or SOA aging processes (Graham et al., 2003a, b).

These results for the Amazon tropical rain forest can be compared to other recent observations over tropical forested West Africa during the wet season (Capes et al., 2009) as well as measurements above a maritime tropical forest in Borneo, Malaysia (Robinson et al., 2010). Based on these three sets of measurements, the organic mass concentrations (ca. $1( \pm 30 \%)$ ) are consistently lower for the tropical rainforest compared to temperate coniferous forests (Zhang et al., 2007). The three tropical locations also have in common that secondary organic material is identified as the major organic component in the submicron mode.

\subsubsection{Thermodenuder analysis}

The temperature sensitivities of the number-diameter distributions and the mass spectra of aerosol particles can provide information on their chemical and physical properties. Toward this purpose, a thermodenuder (TD) was operated in front of the MPI-PC AMS from 5 to 14 March 2008 and in front of the Lund SMPS from 1 to 12 April 2008. TD-AMS measurements have never before been reported for 


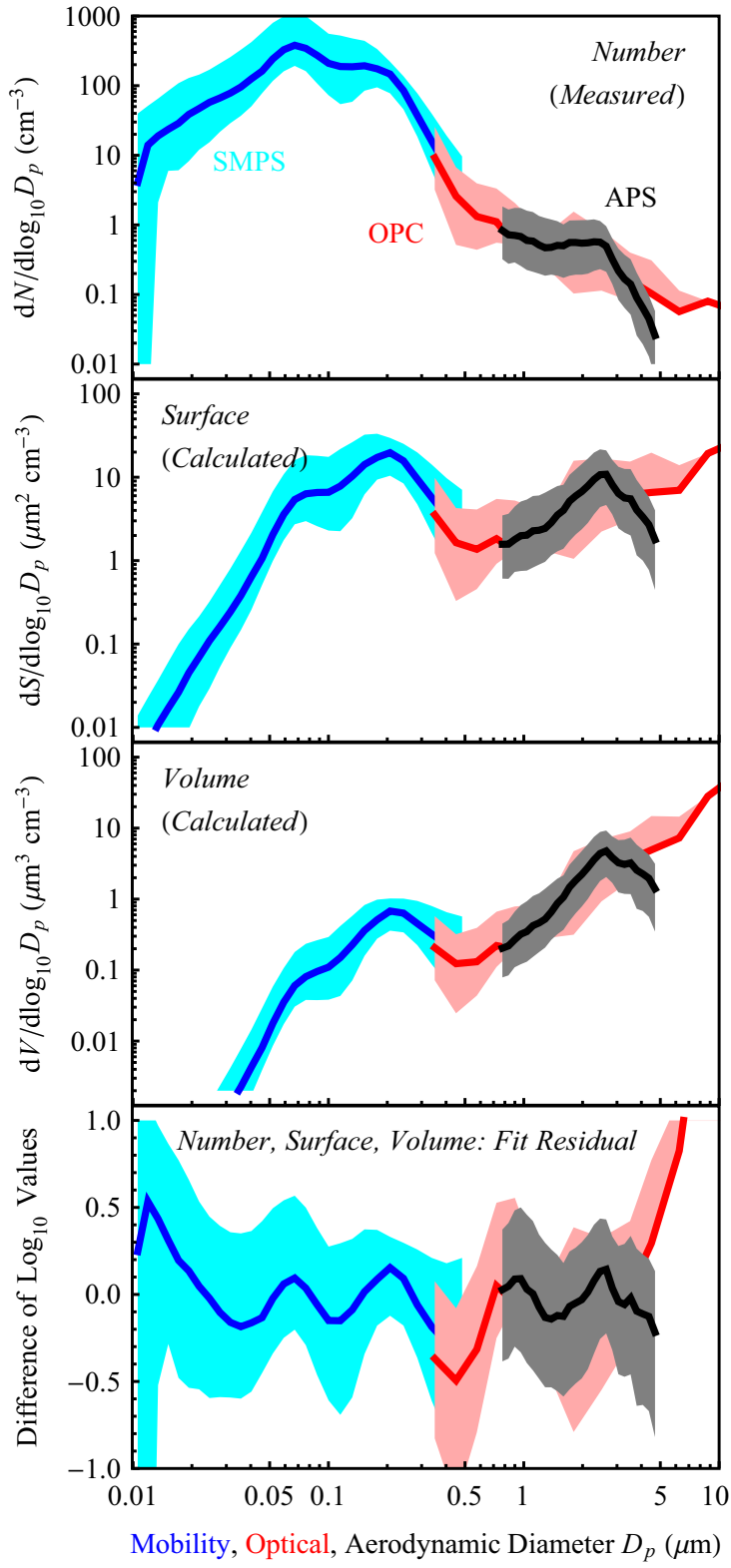

Fig. 12. The top panel shows the measured number-diameter distribution $d N / d \log D_{p}$ from $10 \mathrm{~nm}$ to $10 \mu \mathrm{m}$ for 6 to 14 March 2008 . The distribution is a composite of measurements from a scanning mobility particle sizer (SMPS), an optical particle counter (OPC), and an ultraviolet aerodynamic particle sizer (UV-APS). The central lines show the median during the time period, and the shaded regions represent the 10- and 90-percentiles of the distribution of observations. Shown in the middle panels are the surface-diameter and volume-diameter distributions calculated from the number-diameter distribution. The bottom panel shows the difference of $\log _{10}$ values between measurement and calculation (i.e., the residual) for the lognormal parameters given in Table 3 . The residuals of $\log _{10}$ values are identical for number, surface, and volume distributions.

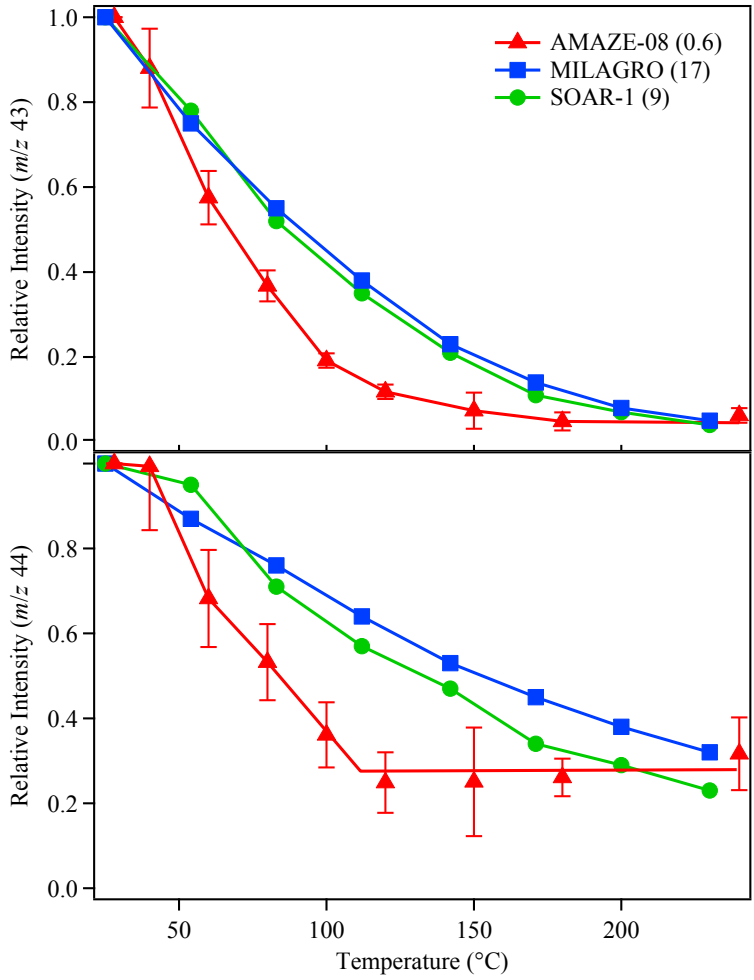

Fig. 13. Thermograms showing the relative signal intensity at $\mathrm{m} / \mathrm{z}$ $43\left(\mathrm{C}_{2} \mathrm{H}_{3} \mathrm{O}^{+}\right)$in the top panel and $m / z, 44\left(\mathrm{CO}_{2}^{+}\right)$in the bottom panel for the organic component of the particle mass spectra on 13 March 2008. Signal intensity is for unit mass resolution. The thermograms were corrected for diffusion losses inside the thermodenuder using the approach described by Huffman et al. (2008). The ambient-temperature flow rate through the thermodenuder was $0.6 \mathrm{Lpm}$. Thermograms for aerosol sampled during the MILAGRO and SOAR campaigns (Huffman et al., 2009b), which represent two polluted megacities, are also included in the figure. The numbers inside the parentheses in the figure legend indicate the organic mass loading $\left(\mu \mathrm{g} \mathrm{m}^{-3}\right)$ of each measurement prior to thermodenuder treatment. The lines in the figure are to guide the eye and do not represent a model fit.

pristine locations such as the Amazon. Although the TDSMPS data were collected after the conclusion of AMAZE08 , the pristine conditions of the wet season still prevailed during that time.

The experimental setups for the TD-SMPS and the TDAMS during AMAZE-08 largely followed the descriptions of Wehner et al. (2002) and Huffman et al. (2008), respectively. The sampling protocol in AMAZE-08, however, switched between the heated thermodenuder and an ambient-temperature bypass every $10 \mathrm{~min}$, with a variable thermodenuder temperature between 70 and $300^{\circ} \mathrm{C}$. Compared to the megacity environments investigated by Huffman et al. (2009b) using a TD-AMS, longer sampling intervals were employed during AMAZE-08, in part because of the low mass concentrations. 
A TD-AMS thermogram was collected across 25 to $240{ }^{\circ} \mathrm{C}$ on 13 March 2008, corresponding to a time period of pristine conditions (Chen et al., 2009). Figure 13 shows the losscorrected thermograms of the relative signal intensity at $\mathrm{m} / \mathrm{z}$ 43 (mainly $\mathrm{C}_{2} \mathrm{H}_{3} \mathrm{O}^{+}$) in the top panel and $\mathrm{m} / \mathrm{z}, 44$ (mainly $\mathrm{CO}_{2}^{+}$) in the bottom panel for the organic component of the particle mass spectra. Relative signal is calculated as the signal intensity at the warmer temperature divided by that at ambient temperature. The thermograms of the pristine particles of the Amazon Basin differ substantially at both $\mathrm{m} / \mathrm{z}, 43$ and $\mathrm{m} / \mathrm{z}, 44$ from those of organic particles in polluted metropolitan of southern California (SOAR) and Mexico City (MILAGRO) (Huffman et al., 2009a,b). Specifically, for pristine compared to polluted conditions, the relative signal intensity decreases much more with increasing temperature. This comparison is consistent with the large-scale production of biogenic secondary organic material within the Basin. Urban primary and secondary organic material (i.e., having a high fraction of anthropogenic precursors) is less volatile than biogenic secondary organic material (Huffman et al., 2009a,b). The lower volatility of SOAR/MILAGRO compared to AMAZE-08 might also be explained in part by the presence of inorganic and black-carbon components that are commonly internally mixed with organic material in many urban areas, in contrast to the organic-dominated composition of individual particles in the Amazon Basin.

Also apparent in Fig. 13 is that for temperatures warmer than 120 to $150^{\circ} \mathrm{C}$ the AMAZE-08 signal intensities for both $\mathrm{m} / \mathrm{z}, 43$ and $\mathrm{m} / \mathrm{z}, 44$ no longer change within the measurement uncertainty. This behavior can be contrasted with the continuous decrease in the intensities of these ions for the polluted conditions of MILAGRO and SOAR campaigns. The difference might be an indication of the presence of refractory oligomers. Although this explanation concerning oligomers is speculative, it is consistent with the results of chamber experiments that were designed to represent the production of secondary organic material in the Amazon Basin (King et al., 2010).

Except for the thermogram collected on 13 March, the TD-AMS measurements were conducted at a fixed thermodenuder temperature of $90^{\circ} \mathrm{C}$. The observations show that the organic mass concentration typically decreases by more than $55 \%$ following thermodenuder treatment. The sulfate mass concentration decreases by $10 \%$, indicating the preferential volatility of the organic material. For times during which the organic mass concentrations are relatively high, an even larger fraction of up to $70 \%$ of the organic material is removed. For comparison to these observations in the Amazon, thermodenuder treatment at $90^{\circ} \mathrm{C}$ leads to the removal of $65 \%$ of the secondary organic material produced in environmental chambers by the oxidation of isoprene and $\alpha$-pinene (Huffman et al., 2009a; Poulain et al., 2009; King et al., 2010).
The TD-SMPS measurements show that the accumulationmode particles (ca. $200 \mathrm{~nm}$ ) are more volatile than their Aitken-mode counterparts (ca. $90 \mathrm{~nm})$. The accumulationmode is nearly absent after exposure to $300^{\circ} \mathrm{C}$, in contrast to the number concentration of the Aitken mode which decreases by just 15 to $20 \%$ at that temperature. The implication of the different volatilities is a substantial difference in chemical composition between the two particle modes, suggestive of different dominant sources for the particle components. In support of this conclusion, the organic mass spectra of the Harvard AMS show clear differences between the two particle modes. Based on the theory of the Hoppel minimum (Martin et al., 2010), the secondary organic components of the Aitken mode are produced by gas-toparticle chemical pathways whereas the components in the accumulation mode are produced in large part by aqueousphase pathways in cloud water. The idea of distinct sources for the two modes is also consistent with the observed homogeneity within a mode, as demonstrated by a uniform shift in the mode diameter with heat treatment (i.e., as opposed to splitting into separate modes or a broadening of the mode width). Across the measurement time period, the ratios of the particle volume concentration (as determined by the SMPS measurements) after thermodenuder treatment to that recorded for the ambient-temperature bypass varied by at most $10 \%$, which suggests a stable steady state among the sources and sinks of secondary organic material within the Amazon Basin.

\subsubsection{Hydrometeor phase in clouds}

The presence of ice in clouds influences precipitation, cloud lifetime, and radiative forcing (Harrington and Olsson, 2001; Petersen and Rutledge, 2001; Zuidema et al., 2005); moreover, in the Amazon Basin, lightning frequency and instantaneous rain rate are highly correlated with cloud ice water content (Petersen and Rutledge, 2001). Ice nuclei are those particles that initiate ice formation in clouds at temperatures warmer than $-36{ }^{\circ} \mathrm{C}$, and they significantly influence the formation of mixed-phase clouds and precipitation for ice crystal number concentrations that exceed about $10^{-3}$ to $10^{-2}$ crystals $\mathrm{cm}^{-3}$ at cloud top (Fletcher, 1961). Determining the temperature at which ice nuclei concentrations exceed $10^{-3} \mathrm{~cm}^{-3}$ can therefore provide insight into regional cloud processes. As part of AMAZE-08, Prenni et al. (2009a) made ground-based measurements and reported average icenuclei concentrations of $10^{-2} \mathrm{~cm}^{-3}$ at $-30^{\circ} \mathrm{C}$, decreasing to $10^{-3} \mathrm{~cm}^{-3}$ at $-20^{\circ} \mathrm{C}$. Even lower numbers, nearly below the detection limit of the instrument, were found at warmer temperatures. Concentrations of $10^{-2}$ to $10^{-3} \mathrm{~cm}^{-3}$ corresponded to 1 particle in $10^{4}$ to $10^{5}$ based on the AMAZE-08 median concentration of 320 particles $\mathrm{cm}^{-3}$

For the purpose of exploring whether ground-based ice nuclei measurements are indicative of ice nucleation at higher altitudes and more broadly in the Amazon Basin, Fig. 14 
herein introduces an additional analysis that makes use of MODIS-retrieved hydrometeor phase of clouds in a radius of $500 \mathrm{~km}$ surrounding the AMAZE-08 measurement site (Platnick et al., 2003). In the analysis, phase refers to one of ice, mixed-phase, liquid, or undetermined. The MODIS cloud algorithm uses differences in water and ice optical properties at 8.5 and $11 \mu \mathrm{m}$ to derive the hydrometeor phase (Platnick et al., 2003). Cloud-top pressure and temperature are derived using a $\mathrm{CO}_{2}$-slicing technique. The derivations of hydrometeor phase are conducted for each cloudy scene viewed in the infrared at a resolution of approximately $5 \times 5 \mathrm{~km}^{2}$ at satellite nadir. The results are stored in the MODIS level-2 5-min cloud products.

Consistent with the ground-based ice nuclei measurements of Prenni et al. (2009a), Fig. 14 shows that ice-free clouds were rarely observed for temperatures colder than $-20^{\circ} \mathrm{C}$, with ice-only clouds becoming progressively more dominant at the colder temperatures. Extension of this result more broadly throughout the Amazon Basin suggests that precipitation from cold-cloud processes can be expected with progressive frequency for cloud-top temperatures of $-20^{\circ} \mathrm{C}$ and colder (i.e., as represented in Fig. 14). These results are similar to those reported by Hanna et al. (2008), who examined the correlation between satellite-inferred cloud-top temperatures and snowfall patterns over the contiguous United States. Snow did not form for temperatures warmer than $-15^{\circ} \mathrm{C}$. To explain this observation, Hanna et al. suggested that there was an absence of sufficient IN. The good agreement between the ground-based measurements of ice nuclei at -20 to $-30^{\circ} \mathrm{C}$ during AMAZE- 08 and the corresponding MODIS-based observations of significant ice in clouds at these temperatures suggests that the surface measurements provide useful information for describing ice formation at higher altitudes.

\section{Conclusions}

The scientific objective of AMAZE-08 was to understand the formation, transformations, and cloud-forming properties of fine- and coarse-mode biogenic natural aerosol particles, especially as related to their effects on cloud activation and regional climate. AMAZE-08 investigated the relationship among plant emissions (Karl et al., 2009), atmospheric particle mass concentrations (Chen et al., 2009), and concentrations of cloud condensation nuclei (Gunthe et al., 2009) and ice nuclei (Prenni et al., 2009a). AMAZE08 deployed for the first time several advanced instruments to Amazonia, including an Aerodyne Aerosol Mass Spectrometer for on-line chemical characterization of aerosol particles (Chen et al., 2009), a DMA-CCNC setup for sizeresolved CCN measurements (Gunthe et al., 2009), an ice nuclei counter (Prenni et al., 2009a), and a Raman LIDAR for long-term vertical profiling (Ansmann et al., 2009). AMAZE-08 provided chemical measurements of particles

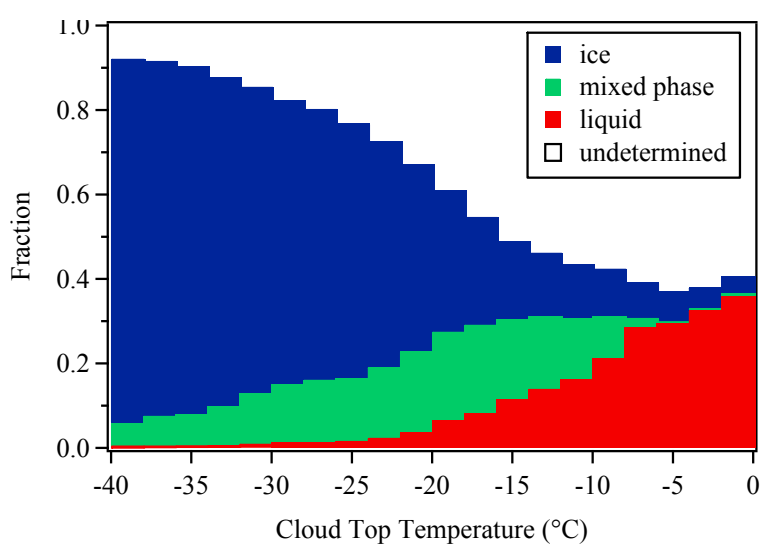

Fig. 14. MODIS-indicated hydrometeor phase of clouds for the geographic region and time period of AMAZE-08. Plotted against cloud-top temperature is the fraction of ice (blue), mixed phase (green), and liquid clouds (red). The fraction is made whole by a white region representing the fraction of time during which hydrometeor phase could not be determined.

on 1 to $5 \mathrm{~min}$ timescales (Chen et al., 2009), allowing insight into processes and mechanisms, compared to earlier work that was limited to daytime and nighttime averages (Martin et al., 2010).

The results presented in this overview paper of AMAZE08 concentrated on the objective of understanding the formation, transformations, and cloud-forming properties of biogenic natural aerosol particles. Parameters of a two-mode lognormal distribution to describe the number-diameter distribution from $10 \mathrm{~nm}$ to $10 \mu \mathrm{m}$ are presented in Table 3, serving as a reference for the Amazon Basin in the wet season and representing the natural aerosol system in the absence of anthropogenic influence. The median number concentration during AMAZE-08 was $321 \mathrm{~cm}^{-3}$, showing that typical continental rural locations in the Northern Hemisphere having concentrations more than ten times this value represent the influence of anthropogenic activities and show that aerosol cycles are highly disrupted by human activities. Cloud microphysics (including brightness, persistence, and precipitation) are sensitive to variable particle concentrations below $1000 \mathrm{~cm}^{-3}$ so that the modern-day separation of continental and marine clouds appears as a result of human activities. The observations recorded in AMAZE-08 provide a baseline knowledge of biogenic particles and therefore assist in identifying separate (as well as synergistic) behavior between natural and anthropogenic particles.

A main finding of AMAZE-08 is evidence of large-scale production of secondary organic material (Chen et al., 2009; Pöschl et al., 2010). Biogenic feedstock of the plant emissions is continuously converted, largely by $\mathrm{OH}$ radical chemistry driven by high water vapor and high actinic flux, into oxidized secondary products. Secondary production also occurs in cloud water. Work to identify the relative importance 
of gas-phase compared to aqueous-phase pathways is ongoing in the data analysis of AMAZE-08. Compared to the dominance of secondary organic material, the results of AMAZE-08 place an upper limit of 5\% on the mass contribution by primary biological aerosol particles to the submicron mass concentration. Size-resolved CCN activity (after normalization for the physics of the size dependence) is also explained by the chemical properties of the secondary organic components. This general finding of active secondary organic production is not contradicted by the observation that IN concentrations are dominated by primary particles because the IN represent just 1 in $10^{4}$ to $10^{5}$ of the submicron particles. Therefore, biological emissions of VOCs regulate $\mathrm{CCN}$ activity whereas biological emissions of PBAPs influence IN concentrations.

We can speculate that two unique observations from the Amazon Basin, specifically the observation of nearly pure liquid organic particles in the Amazonian atmosphere (Pöschl et al., 2010) and the absence of new particle formation at ground level, are related to one another. The low inBasin sulfur concentrations argue for a necessary role of organic molecules (possibly at mid- or high altitude) in the formation of new particles in the Amazon Basin, although such a mechanism remains to be experimentally and observationally validated (Martin et al., 2010). This explanation, if borne out, implies that human activities drastically alter the life cycle of atmospheric particles. Natural mechanisms of new particle formation, as witnessed in the Amazon, are replaced with mechanisms driven by anthropogenic sulfur emissions at most locations worldwide, although natural sulfur emissions by volcanoes and oceanic sources can also be important for new particle formation for some locations and times.

\section{Supplementary material related to this article is available online at: http://www.atmos-chem-phys.net/10/11415/2010/ acp-10-11415-2010-supplement.pdf.}

Acknowledgements. Support was received from the US National Science Foundation, the Brazil LBA Millennium Institute, the Max Planck Society, the Brazilian Large-Scale Biosphere-Atmosphere Experiment, the European Integrated project on Aerosol Cloud Climate and Air Quality Interactions (EUCAARI), and the US National Aeronautics and Space Administration. STM also acknowledges support from Humboldt Research Fellowship: Summer Research Fellowship for US Scientists and Scholars and a Visiting Researcher Award, State of São Paulo Research Foundation (FAPESP), Brazil. We thank all technical and logistical support staff of the LBA office in Manaus. The authors gratefully acknowledge the NOAA Air Resources Laboratory for provision of the HYSPLIT transport and dispersion model (http://www.arl.noaa.gov/ready.html) (Draxler and Hess, 1998).

Edited by: R. Cohen

\section{References}

Ahlm, L., Nilsson, E. D., Krejci, R., Mårtensson, E. M., Vogt, M., and Artaxo, P.: Aerosol number fluxes over the Amazon rain forest during the wet season, Atmos. Chem. Phys., 9, 9381-9400, doi:10.5194/acp-9-9381-2009, 2009.

Alfarra, M. R., Prevot, A. S. H., Szidat, S., Sandradewi, J., Weimer, S., Lanz, V. A., Schreiber, D., Mohr, M., and Baltensperger, U.: Identification of the mass spectral signature of organic aerosols from wood burning emissions, Environ. Sci. Technol., 41, 5770-5777, 2007.

Althausen, D., Engelmann, R., Baars, H., Heese, B., Ansmann, A., Müller, D., and Komppula, M.: Portable Raman Lidar Polly^XT for automated profiling of aerosol backscatter, extinction, and depolarization, J. Atmos. Ocean. Tech., 26, 2366-2378, 2009.

Andreae, M. O.: Aerosols before pollution, Science, 315, 50-51, 2007.

Andreae, M. O.: Correlation between cloud condensation nuclei concentration and aerosol optical thickness in remote and polluted regions, Atmos. Chem. Phys., 9, 543-556, doi:10.5194/acp-9-543-2009, 2009.

Andreae, M. O. and Crutzen, P. J.: Atmospheric aerosols: biogeochemical sources and role in atmospheric chemistry, Science, 276, 1052-1058, 1997.

Andreae, M. O., Berresheim, H., Bingemer, H., Jacob, D. J., Lewis, B. L., Li, S. M., and Talbot, R. W.: The atmospheric sulfur cycle over the Amazon Basin, 2. Wet season, J. Geophys. Res., 95, 16813-16824, 1990.

Andreae, M. O., Artaxo, P., Brandao, C., Carswell, F. E., Ciccioli, P., da Costa, A. L., Culf, A. D., Esteves, J. L., Gash, J. H. C., Grace, J., Kabat, P., Lelieveld, J., Malhi, Y., Manzi, A. O., Meixner, F. X., Nobre, A. D., Nobre, C., Ruivo, M., Silva-Dias, M. A., Stefani, P., Valentini, R., von Jouanne, J., and Waterloo, M. J.: Biogeochemical cycling of carbon, water, energy, trace gases, and aerosols in Amazonia: the LBA-EUSTACH experiments, J. Geophys. Res., 107, 8066, doi:10.1029/2001JD000524, 2002.

Ansmann, A., Baars, H., Tesche, M., Muller, D., Althausen, D., Engelmann, R., Pauliquevis, T., and Artaxo, P.: Dust and smoke transport from Africa to South America: LIDAR profiling over Cape Verde and the Amazon rainforest, Geophys. Res. Lett., 2009, L11802, doi:10.1029/2009GL037923, 2009.

Araujo, A. C., Nobre, A. D., Kruijt, B., Elbers, J. A., Dallarosa, R., Stefani, P., von Randow, C., Manzi, A. O., Culf, A. D., Gash, J. H. C., Valentini, R., and Kabat, P.: Comparative measurements of carbon dioxide fluxes from two nearby towers in a central Amazonian rainforest: the Manaus LBA site, J. Geophys. Res., 107, 8090, doi:10.1029/2001JD000676, 2002.

Artaxo, P., Maenhaut, W., Storms, H., and Vangrieken, R.: Aerosol characteristics and sources for the Amazon Basin during the wet season, J. Geophys. Res., 95, 16971-16985, 1990.

Baars, H., Ansmann, A., Engelmann, R., and Althausen, D.: Continuous monitoring of the boundary-layer top with lidar, Atmos. Chem. Phys., 8, 7281-7296, doi:10.5194/acp-8-7281-2008, 2008.

Barth, M., McFadden, J. P., Sun, J. L., Wiedinmyer, C., Chuang, P., Collins, B., Griffin, R., Hannigan, M., Karl, T., Kim, S. W., Lasher-Trapp, S., Levis, S., Litvak, M., Mahowald, N., Moore, K., Nandi, S., Nemitz, E., Nenes, A., Potosnak, M., Raymond, T. M., Smith, J., Still, C., and Stroud, C.: 
Coupling between land ecosystems and the atmospheric hydrologic cycle through biogenic aerosol pathways, B. Am. Meteorol. Soc., 86, 1738-1742, 2005.

Ben-Ami, Y., Koren, I., Rudich, Y., Artaxo, P., Martin, S. T., and Andreae, M. O.: Transport of Saharan dust from the Bodélé depression to the Amazon Basin: a case study, Atmos. Chem. Phys., 10, 7533-7544, 2010,

http://www.atmos-chem-phys.net/10/7533/2010/.

Capes, G., Murphy, J. G., Reeves, C. E., McQuaid, J. B., Hamilton, J. F., Hopkins, J. R., Crosier, J., Williams, P. I., and Coe, H.: Secondary organic aerosol from biogenic VOCs over West Africa during AMMA, Atmos. Chem. Phys., 9, 3841-3850, doi:10.5194/acp-9-3841-2009, 2009.

Carlton, A. G., Turpin, B. J., Altieri, K. E., Seitzinger, S. P., Mathur, R., Roselle, S. J., and Weber, R. J.: CMAQ model performance enhanced when in-cloud secondary organic aerosol is included: comparisons of organic carbon predictions with measurements, Environ. Sci. Technol., 42, 8798-8802, 2008.

Carlton, A. G., Wiedinmyer, C., and Kroll, J. H.: A review of Secondary Organic Aerosol (SOA) formation from isoprene, Atmos. Chem. Phys., 9, 4987-5005, doi:10.5194/acp-9-4987-2009, 2009.

Chen, Q., Farmer, D. K., Schneider, J., Zorn, S. R., Heald, C. L., Karl, T. G., Guenther, A., Allan, J. D., Robinson, N., Coe, H., Kimmel, J. R., Pauliquevis, T., Borrmann, S., Pöschl, U., Andreae, M. O., Artaxo, P., Jimenez, J. L., and Martin, S. T.: Mass spectral characterization of submicron biogenic organic particles in the Amazon Basin, Geophys. Res. Lett., 36, L20806, doi:10.1029/2009GL039880, 2009.

Chung, S. H. and Seinfeld, J. H.: Global distribution and climate forcing of carbonaceous aerosols, J. Geophys. Res., 107, 4407, doi:10.1029/2001JD001397, 2002.

Claeys, M., Graham, B., Vas, G., Wang, W., Vermeylen, R., Pashynska, V., Cafmeyer, J., Guyon, P., Andreae, M. O., Artaxo, P., and Maenhaut, W.: Formation of secondary organic aerosols through photooxidation of isoprene, Science, 303, 1173-1176, 2004.

de Gouw, J. and Jimenez, J. L.: Organic aerosols in the earth's atmosphere, Environ. Sci. Technol., 43, 7614-7618, 2009.

de Gouw, J. A., Middlebrook, A. M., Warneke, C., Goldan, P. D., Kuster, W. C., Roberts, J. M., Fehsenfeld, F. C., Worsnop, D. R., Canagaratna, M. R., Pszenny, A. A. P., Keene, W. C., Marchewka, M., Bertman, S. B., and Bates, T. S.: Budget of organic carbon in a polluted atmosphere: Results from the New England Air Quality Study in 2002, J. Geophys. Res., 110, D16305, doi:10.1029/2004JD005623, 2005.

DeCarlo, P. F., Kimmel, J. R., Trimborn, A., Jayne, J. T., Aiken, A. C., Gonin, M., Fuhrer, K., Horvath, T., Docherty, K. S., Worsnop, D. R., and Jimenez, J. L.: A field-deployable high-resolution time-of-flight aerosol mass spectrometer, Anal. Chem., 78, 8281-8289, 2006.

Draxler, R. R. and Hess, G. D.: An overview of the Hysplit 4 modelling system for trajectories, dispersion, and deposition, Aust. Meteorol. Mag., 47, 295-308, 1998.

Ervens, B., Carlton, A. G., Turpin, B. J., Altieri, K. E., Kreidenweis, S. M., and Feingold, G.: Secondary organic aerosol yields from cloud-processing of isoprene oxidation products, Geophys. Res. Lett., 35, L02816, doi:10.1029/2007GL031828, 2008.

Farmer, D. K., Matsunaga, A., Docherty, K. S., Surratt, J. D., Seinfeld, J. H., Ziemann, P. J., and Jimenez, J. L.: Response of an aerosol mass spectrometer to organonitrates and organosulfates and implications for atmospheric chemistry, P. Natl. Acad. Sci. USA, 107, 6670-6675, doi:10.1073/pnas.0912340107, 2010.

Fisch, G., Tota, J., Machado, L. A. T., Dias, M., Lyra, R. F. D., Nobre, C. A., Dolman, A. J., and Gash, J. H. C.: The convective boundary layer over pasture and forest in Amazonia, Theor. Appl. Climatol., 78, 47-59, 2004.

Fletcher, N. H.: Freezing nuclei, meteors, and rainfall - do tiny particles from meteor streams influence rainfall over the earth's continents?, Science, 134, 361-367, 1961.

Formenti, P., Andreae, M. O., Lange, L., Roberts, G., Cafmeyer, J., Rajta, I., Maenhaut, W., Holben, B. N., Artaxo, P., and Lelieveld, J.: Saharan dust in Brazil and Suriname during the Large-Scale Biosphere-Atmosphere Experiment in Amazonia (LBA) - Cooperative LBA Regional Experiment (CLAIRE) in March 1998, J. Geophys. Res., 106, 14919-14934, 2001.

Fraser, M. P. and Lakshmanan, K.: Using levoglucosan as a molecular marker for the long-range transport of biomass combustion aerosols, Environ. Sci. Technol., 34, 4560-4564, 2000.

Freutel, F.: Identifizierung charakteristischer massenspektrometrischer Marker fr primaere biologische Aerosolpartikel, M.S. Thesis, University Mainz, 2009 (in German).

Fuzzi, S., Decesari, S., Facchini, M. C., Cavalli, F., Emblico, L., Mircea, M., Andreae, M. O., Trebs, I., Hoffer, A., Guyon, P., Artaxo, P., Rizzo, L. V., Lara, L. L., Pauliquevis, T., Maenhaut, W., Raes, N., Chi, X. G., Mayol-Bracero, O. L., SotoGarcia, L. L., Claeys, M., Kourtchev, I., Rissler, J., Swietlicki, E., Tagliavini, E., Schkolnik, G., Falkovich, A. H., Rudich, Y., Fisch, G., and Gatti, L. V.: Overview of the inorganic and organic composition of size-segregated aerosol in Rondonia, Brazil, from the biomass-burning period to the onset of the wet season, J. Geophys. Res., 112, D01201, doi:10.1029/2005JD006741, 2007.

Garstang, M., Ulanski, S., Greco, S., Scala, J., Swap, R., Fitzjarrald, D., Martin, D., Browell, E., Shipman, M., Connors, V., Harriss, R., and Talbot, R.: The Amazon Boundary-Layer Experiment (ABLE-2B): a meteorological perspective, B. Am. Meteorol. Soc., 71, 19-32, 1990.

Gerab, F., Artaxo, P., Gillett, R., and Ayers, G.: PIXE, PIGE and ion chromatography of aerosol particles from northeast Amazon Basin, Nucl. Instrum. Meth. B, 137, 955-960, 1998.

Giglio, L., Csiszar, I., and Justice, C. O.: Global distribution and seasonality of active fires as observed with the Terra and Aqua MODIS sensors, J. Geophys. Res., 111, G02016, doi:10.1029/2005JG000142, 2006.

Gilbert, G. S.: Nocturnal fungi: airborne spores in the canopy and understory of a tropical rain forest, Biotropica, 37, 462-464, 2005.

Goldstein, A. H. and Galbally, I. E.: Known and unexplored organic constituents in the earth's atmosphere, Environ. Sci. Technol., 41, 1514-1521, 2007.

Graham, B., Guyon, P., Maenhaut, W., Taylor, P. E., Ebert, M., Matthias-Maser, S., Mayol-Bracero, O. L., Godoi, R. H. M., Artaxo, P., Meixner, F. X., Moura, M. A. L., Rocha, C., Van Grieken, R., Glovsky, M. M., Flagan, R. C., and Andreae, M. O.: Composition and diurnal variability of the natural Amazonian aerosol, J. Geophys. Res., 108, 4765, doi:4710.1029/2003JD004049, 2003a.

Graham, B., Guyon, P., Taylor, P. E., Artaxo, P., Maenhaut, W., Glovsky, M. M., Flagan, R. C., and Andreae, M. O.: Organic 
compounds present in the natural Amazonian aerosol: Characterization by gas chromatography-mass spectrometry, J. Geophys. Res., 108, 4766, doi:10.1029/2003JD003990, 2003b.

Guenther, A., Hewitt, C. N., Erickson, D., Fall, R., Geron, C., Graedel, T., Harley, P., Klinger, L., Lerdau, M., McKay, W. A., Pierce, T., Scholes, B., Steinbrecher, R., Tallamraju, R., Taylor, J., and Zimmerman, P.: A global model of natural volatile organic compound emissions, J. Geophys. Res., 100, 8873-8892, 1995.

Gunthe, S. S., King, S. M., Rose, D., Chen, Q., Roldin, P., Farmer, D. K., Jimenez, J. L., Artaxo, P., Andreae, M. O., Martin, S. T., and Pöschl, U.: Cloud condensation nuclei in pristine tropical rainforest air of Amazonia: size-resolved measurements and modeling of atmospheric aerosol composition and CCN activity, Atmos. Chem. Phys., 9, 7551-7575, doi:10.5194/acp-9-75512009, 2009.

Guyon, P., Graham, B., Roberts, G. C., Mayol-Bracero, O. L., Maenhaut, W., Artaxo, P., and Andreae, M. O.: In-canopy gradients, composition, sources, and optical properties of aerosol over the Amazon forest, J. Geophys. Res., 108, 4591, doi:10.1029/2003JD003465, 2003a.

Guyon, P., Boucher, O., Graham, B., Beck, J., MayolBracero, O. L., Roberts, G. C., Maenhaut, W., Artaxo, P., and Andreae, M. O.: Refractive index of aerosol particles over the Amazon tropical forest during LBA-EUSTACH 1999, J. Aerosol Sci., 34, 883-907, 2003b.

Guyon, P., Graham, B., Roberts, G. C., Mayol-Bracero, O. L., Maenhaut, W., Artaxo, P., and Andreae, M. O.: Sources of optically active aerosol particles over the Amazon forest, Atmos. Environ., 38, 1039-1051, 2004.

Hallquist, M., Wenger, J. C., Baltensperger, U., Rudich, Y., Simpson, D., Claeys, M., Dommen, J., Donahue, N. M., George, C., Goldstein, A. H., Hamilton, J. F., Herrmann, H., Hoffmann, T., Iinuma, Y., Jang, M., Jenkin, M. E., Jimenez, J. L., Kiendler-Scharr, A., Maenhaut, W., McFiggans, G., Mentel, Th. F., Monod, A., Prévôt, A. S. H., Seinfeld, J. H., Surratt, J. D., Szmigielski, R., and Wildt, J.: The formation, properties and impact of secondary organic aerosol: current and emerging issues, Atmos. Chem. Phys., 9, 5155-5236, doi:10.5194/acp-95155-2009, 2009.

Hanna, J. W., Schultz, D. M., and Irving, A. R.: Cloud-top temperatures for precipitating winter clouds, J. Appl. Meteorol. Climatol., 47, 351-359, 2008.

Harrington, J. Y. and Olsson, P. Q.: On the potential influence of ice nuclei on surface-forced marine stratocumulus cloud dynamics, J. Geophys. Res., 106, 27473-27484, 2001.

Heald, C. L., Jacob, D. J., Park, R. J., Russell, L. M., Huebert, B. J., Seinfeld, J. H., Liao, H., and Weber, R. J.: A large organic aerosol source in the free troposphere missing from current models, Geophys. Res. Lett., 32, L18809, doi:10.1029/2005GL023831, 2005.

Heald, C. L., Henze, D. K., Horowitz, L. W., Feddema, J., Lamarque, J.-F., Guenther, A., Hess, P. G., Vitt, F., Seinfeld, J. H., Goldstein, A. H., and Fung, I.: Predicted change in global secondary organic aerosol concentrations in response to future climate, emissions, and land use change, J. Geophys. Res., 113, D05211, doi:10.1029/2007JD009092, 2008.

Heald, C. L., Kroll, J. H., Jimenez, J. L., Docherty, K. S., DeCarlo, P. F., Aiken, A. C., Chen, Q., Martin, S. T., Farmer, D. K., and Artaxo, P.: A simplified description of the evolution of organic aerosol composition in the atmosphere, Geophys. Res. Lett., 37, L08803, doi:10.1029/2010GL042737, 2010.

Henze, D. K. and Seinfeld, J. H.: Global secondary organic aerosol from isoprene oxidation, Geophys. Res. Lett., 33, L09812, doi:10.1029/2006GL025976, 2006.

Hinds, W. H.: Aerosol Technology, Wiley, New York, USA, 75110, Chapter 4, 1999.

Huffman, J. A., Ziemann, P. J., Jayne, J. T., Worsnop, D. R., and Jimenez, J. L.: Development and characterization of a fast-stepping/scanning thermodenuder for chemically-resolved aerosol volatility measurements, Aerosol Sci. Tech., 42, 395407, 2008.

Huffman, J. A., Docherty, K. S., Mohr, C., Cubison, M. J., Ulbrich, I. M., Ziemann, P. J., Onasch, T. B., and Jimenez, J. L.: Chemically-resolved volatility measurements of organic aerosol from different sources, Environ. Sci. Technol., 43, 5351-5357, 2009a.

Huffman, J. A., Docherty, K. S., Aiken, A. C., Cubison, M. J., Ulbrich, I. M., DeCarlo, P. F., Sueper, D., Jayne, J. T., Worsnop, D. R., Ziemann, P. J., and Jimenez, J. L.: Chemically-resolved aerosol volatility measurements from two megacity field studies, Atmos. Chem. Phys., 9, 7161-7182, doi:10.5194/acp-9-71612009, 2009b.

Huffman, J. A., Treutlein, B., and Pöschl, U,: Fluorescent biological aerosol particle concentrations and size distributions measured with an Ultraviolet Aerodynamic Particle Sizer (UV-APS) in Central Europe, Atmos. Chem. Phys., 10, 3215-3233, 2010, http://www.atmos-chem-phys.net/10/3215/2010/.

Jaenicke, R.: Abundance of cellular material and proteins in the atmosphere, Science, 308, 73-73, 2005.

Karl, T., Guenther, A., Turnipseed, A., Tyndall, G., Artaxo, P., and Martin, S.: Rapid formation of isoprene photo-oxidation products observed in Amazonia, Atmos. Chem. Phys., 9, 7753-7767, doi:10.5194/acp-9-7753-2009, 2009.

Keller, M., Bustamante, M., Gash, J., and Dias, P. (Eds.): Amazonia and Global Change, American Geophysical Union, Geophysical Monograph Series 186, Washington DC, 2009.

Kesselmeier, J., Guenther, A., Hoffmann, T., and Warnke, J.: Natural volatile organic compound (VOC) emissions from plants and their roles in oxidant balance and particle formation, in: Amazonia and Global Change, edited by: Keller, M., Bustamante, M., Gash, J., and Dias, P., Geophysical Monograph Series 186, American Geophysical Union, Washington DC, 2009.

King, S. M., Rosenoern, T., Shilling, J. E., Chen, Q., and Martin, S. T.: Cloud condensation nucleus activity of secondary organic aerosol particles mixed with sulfate, Geophys. Res. Lett., 34, L24806, doi:10.1029/2007GL030390, 2007.

King, S. M., Rosenoern, T., Shilling, J. E., Chen, Q., and Martin, S. T.: Increased cloud activation potential of secondary organic aerosol for atmospheric mass loadings, Atmos. Chem. Phys., 9, 2959-2971, doi:10.5194/acp-9-2959-2009, 2009.

King, S. M., Rosenoern, T., Shilling, J. E., Chen, Q., Wang, Z., Biskos, G., McKinney, K. A., Pöschl, U., and Martin, S. T.: Cloud droplet activation of mixed organic-sulfate particles produced by the photooxidation of isoprene, Atmos. Chem. Phys., 10, 3953-3964, doi:10.5194/acp-10-3953-2010, 2010.

Klinedinst, D. B. and Currie, L. A.: Direct quantification of $\mathrm{PM}_{2.5}$ fossil and biomass carbon within the Northern Front Range Air 
Quality Study's domain, Environ. Sci. Technol., 33, 4146-4154, 1999.

Kroll, J. H. and Seinfeld, J. H.: Chemistry of secondary organic aerosol: formation and evolution of low-volatility organics in the atmosphere, Atmos. Environ., 42, 3593-3624, 2008.

Kroll, J. H., Ng, N. L., Murphy, S. M., Flagan, R. C., and Seinfeld, J. H.: Secondary organic aerosol formation from isoprene photooxidation, Environ. Sci. Technol., 40, 1869-1877, 2006.

Kuhn, U., Andreae, M. O., Ammann, C., Araújo, A. C., Brancaleoni, E., Ciccioli, P., Dindorf, T., Frattoni, M., Gatti, L. V., Ganzeveld, L., Kruijt, B., Lelieveld, J., Lloyd, J., Meixner, F. X., Nobre, A. D., Pöschl, U., Spirig, C., Stefani, P., Thielmann, A., Valentini, R., and Kesselmeier, J.: Isoprene and monoterpene fluxes from Central Amazonian rainforest inferred from towerbased and airborne measurements, and i mplications on the atmospheric chemistry and the local carbon budget, Atmos. Chem. Phys., 7, 2855-2879, doi:10.5194/acp-7-2855-2007, 2007.

Lelieveld, J., Butler, T. M., Crowley, J. N., Dillon, T. J., Fischer, H., Ganzeveld, L., Harder, H., Lawrence, M. G., Martinez, M., Taraborrelli, D., and Williams, J.: Atmospheric oxidation capacity sustained by a tropical forest, Nature, 452, 737-740, 2008.

Levy, R. C., Remer, L., Mattoo, S., Vermote, E., and Kaufman, Y. J.: Second-generation algorithm for retrieving aerosol properties over land from MODIS spectral reflectance, J. Geophys. Res., 112, D13211, doi:10.1029/2006JD007811, 2007.

Lim, H.-J., Carlton, A. G., and Turpin, B. J.: Isoprene forms secondary organic aerosol through cloud processing: model simulations, Environ. Sci. Technol., 39, 4441-4446, 2005.

Liu, P. S. K., Deng, R., Smith, K. A., Williams, L. R., Jayne, J. T., Canagaratna, M. R., Moore, K., Onasch, T. B., Worsnop, D. R., and Deshler, T.: Transmission efficiency of an aerodynamic focusing lens system: comparison of model calculations and laboratory measurements for the Aerodyne Aerosol Mass Spectrometer, Aerosol Sci. Tech., 41, 721-733, 2007.

Martin, C. L., Fitzjarrald, D. R., Garstang, M., Oliveira, A. P., Greco, S., and Browell, E. V.: Structure and growth of the mixing layer over the Amazonian rain forest, J. Geophys. Res., 93, 1361-1375, 1988.

Martin, S. T., Andreae, M. O., Artaxo, P., Baumgardner, D., Chen, Q., Goldstein, A. H., Guenther, A., Heald, C. L., MayolBracero, O. L., McMurry, P. H., Pauliquevis, T., Pöschl, U., Prather, K. A., Roberts, G. C., Saleska, S. R., Silva-Dias, M. A., Spracklen, D. V., Swietlicki, E., and Trebs, I.: Sources and properties of Amazonian aerosol particles, Rev. Geophys., 48, RG2002, doi:10.1029/2008RG000280, 2010.

Matthias-Maser, S. and Jaenicke, R.: The size distribution of primary biological aerosol particles with radii $>0.2 \mu \mathrm{m}$ in an urban/rural influenced region, Atmos. Res., 39, 279-286, 1995.

Millet, D. B., Goldstein, A. H., Holzinger, R., Williams, B. J., Allan, J. D., Jimenez, J. L., Worsnop, D. R., Roberts, J. M., White, A. B., Hudman, R. C., Bertschi, I. T., and Stohl, A.: Chemical characteristics of North American surface layer outflow: Insights from Chebogue Point, Nova Scotia, J. Geophys. Res., 111, D23S53, doi:10.1029/2006JD007287, 2006.

Mircea, M., Facchini, M. C., Decesari, S., Cavalli, F., Emblico, L., Fuzzi, S., Vestin, A., Rissler, J., Swietlicki, E., Frank, G., Andreae, M. O., Maenhaut, W., Rudich, Y., and Artaxo, P.: Importance of the organic aerosol fraction for modeling aerosol hygroscopic growth and activation: a case study in the Amazon
Basin, Atmos. Chem. Phys., 5, 3111-3126, doi:10.5194/acp-53111-2005, 2005.

Pandis, S. N., Harley, R. A., Cass, G. R., and Seinfeld, J. H.: Secondary organic aerosol formation and transport, Atmos. Environ., 26, 2269-2282, 1992.

Pauliquevis, T., Silva-Dias, M. A. F., Manzi, A. O., Gunthe, S. S., Martin, S. T., and Artaxo, P.: On the condensational growth of cloud droplets formed in the pristine atmosphere of the Amazon basin, in preparation, 2010.

Paulot, F., Crounse, J. D., Kjaergaard, H. G., Kurten, A., St. Clair, J. M., Seinfeld, J. H., and Wennberg, P. O.: Unexpected epoxide formation in the gas-phase photooxidation of isoprene, Science, 325, 730-733, 2009.

Peeters, J., Nguyen, T. L., and Vereecken, L.: $\mathrm{HO}_{\mathrm{x}}$ radical regeneration in the oxidation of isoprene, Phys. Chem. Chem. Phys., 11, 5935-5939, 2009.

Petersen, W. A. and Rutledge, S. A.: Regional variability in tropical convection: observations from TRMM, J. Climate, 14, 35663586, 2001.

Platnick, S., King, M. D., Ackerman, S. A., Menzel, W. P., Baum, B. A., Riedi, J. C., and Frey, R. A.: The MODIS cloud products: Algorithms and examples from Terra, IEEE T. Geosci. Remote, 41, 459-473, 2003.

Pöschl, U, Martin, S. T., Sinha, B., Chen, Q, Gunthe, S. S., Huffman, J. A., Borrmann, S., Farmer, D. K., Garland, R. M., Helas, G., Jimenez, J. L., King, S. M., Manzi, A., Mikhailov, E., Pauliquevis, T., Petters, M. D., Prenni, A. J., Roldin, P., Rose, D., Schneider, J., Su, H., Zorn, S. R., Artaxo, P., and Andreae, M. O.: Rainforest aerosols as biogenic nuclei of clouds and precipitation in the Amazon, Science, 329, 1513-1516, 2010.

Poulain, L., Wu, Z., Petters, M. D., Wex, H., Hallbauer, E., Wehner, B., Massling, A., Kreidenweis, S. M., and Stratmann, F.: Towards closing the gap between hygroscopic growth and $\mathrm{CCN}$ activation for secondary organic aerosols - Part 3: Influence of the chemical composition on the hygroscopic properties and volatile fractions of aerosols, Atmos. Chem. Phys., 10, 37753785, doi:10.5194/acp-10-3775-2010, 2010.

Prenni, A. J., Petters, M. D., Kreidenweis, S. M., Heald, C. L., Martin, S. T., Artaxo, P., Garland, R. M., Wollny, A. G., and Pöschl, U.: Relative roles of biogenic emissions and Saharan dust as ice nuclei in the Amazon basin, Nat. Geosci., 2, 402-405, 2009a.

Prenni, A. J., Petters, M. D., Faulhaber, A., Carrico, C. M., Ziemann, P. J., Kreidenweis, S. M., and DeMott, P. J.: Heterogeneous ice nucleation measurements of secondary organic aerosol generated from ozonolysis of alkenes, Geophys. Res. Lett., 36, L06808, doi:10.1029/2008GL036957, 2009b.

Prospero, J. M., Glaccum, R. A., and Nees, R. T.: Atmospheric transport of soil dust from Africa to South America, Nature, 289, 570-572, 1981.

Remer, L. A., Kleidman, R. G., Levy, R. C., Kaufman, Y. J., Tanre, D., Mattoo, S., Martins, J. V., Ichoku, C., Koren, I., Yu, H., and Holben, B. N.: Global aerosol climatology from the MODIS satellite sensors, J. Geophys. Res., 113, D14S07, doi:10.1029/2007JD009661, 2008.

Rissler, J., Swietlicki, E., Zhou, J., Roberts, G., Andreae, M. O., Gatti, L. V., and Artaxo, P.: Physical properties of the submicrometer aerosol over the Amazon rain forest during the wetto-dry season transition - comparison of modeled and mea- 
sured CCN concentrations, Atmos. Chem. Phys., 4, 2119-2143, doi:10.5194/acp-4-2119-2004, 2004.

Roberts, G. C., Andreae, M. O., Zhou, J. C., and Artaxo, P.: Cloud condensation nuclei in the Amazon Basin: "marine" conditions over a continent?, Geophys. Res. Lett., 28, 2807-2810, 2001.

Roberts, G. C., Artaxo, P., Zhou, J. C., Swietlicki, E., and Andreae, M. O.: Sensitivity of CCN spectra on chemical and physical properties of aerosol: a case study from the Amazon Basin, J. Geophys. Res., 107, 8070, doi:10.1029/2001JD000583, 2002.

Roberts, G. C., Nenes, A., Seinfeld, J. H., and Andreae, M. O.: Impact of biomass burning on cloud properties in the Amazon Basin, J. Geophys. Res., 108, 4062, doi:10.1029/2001JD000985, 2003.

Robinson, N. H., Hamilton, J. F., Allan, J. D., Langford, B., Oram, D. E., Chen, Q., Docherty, K., Farmer, D. K., Jimenez, J. L., Ward, M. W., Hewitt, C. N., Barley, M. H., Jenkin, M. E., Rickard, A. R., Martin, S. T., McFiggans, G., and Coe, H.: : Evidence for a significant proportion of secondary organic aerosol from isoprene above a maritime tropical forest, Atmos. Chem. Phys. Discuss., 10, 25545-25576, doi:10.5194/acpd-10-2554520102010.

Rogers, D. C., DeMott, P. J., Kreidenweis, S. M., and Chen, Y. L.: A continuous-flow diffusion chamber for airborne measurements of ice nuclei, J. Atmos. Ocean. Tech., 18, 725-741, 2001.

Schneider, J., Weimer, S., Drewnick, F., Borrmann, S., Helas, G., Gwazec, P., Schmid, O., Andreae, M. O., and Kirchner, U.: Mass spectrometric analysis and aerodynamic properties of various types of combustion-related aerosol particles, Int. J. Mass. Spectrom., 258, 37-49, 2006.

Shilling, J. E., Chen, Q., King, S. M., Rosenoern, T., Kroll, J. H., Worsnop, D. R., DeCarlo, P. F., Aiken, A. C., Sueper, D., Jimenez, J. L., and Martin, S. T.: Loading-dependent elemental composition of $\alpha$-pinene SOA particles, Atmos. Chem. Phys., 9, 771-782, doi:10.5194/acp-9-771-2009, 2009.

Simoneit, B. R. T., Schauer, J. J., Nolte, C. G., Oros, D. R., Elias, V. O., Fraser, M. P., Rogge, W. F., and Cass, G. R.: Levoglucosan, a tracer for cellulose in biomass burning and atmospheric particles, Atmos. Environ., 33, 173-182, 1999.

Sinha, B. W., Huth, J., Hoppe, P., Snee-Pollmann, A., King, S. M., Mikhailov, E., Pöschl, U., Andreae, M. O., and Martin, S. T.: Composition and mixing state of wet season fine mode aerosol collected in the Amazonian tropical rain forest (Manaus, Brazil), Geophys. Res. Abstr., 11, EGU2009-4814, 2009.

Svenningsson, B., Arneth, A., Hayward, S., Holst, T., Massling, A., Swietlicki, E., Hirsikko, A., Junninen, H., Riipinen, I., Vana, M., Dal Maso, M., Hussein, T., and Kulmala, M.: Aerosol particle formation events and analysis of high growth rates observed above a subarctic wetland-forest mosaic, Tellus, 60, 353-364, 2008.

Swap, R., Garstang, M., Greco, S., Talbot, R., and Kållberg, P.: Saharan dust in the Amazon Basin, Tellus B, 44, 133-149, 1992.

Szidat, S., Jenk, T. M., Gaggeler, H. W., Synal, H. A., Fisseha, R., Baltensperger, U., Kalberer, M., Samburova, V., Reimann, S., Kasper-Giebl, A., and Hajdas, I.: Radiocarbon (C-14)-deduced biogenic and anthropogenic contributions to organic carbon (OC) of urban aerosols from Zurich, Switzerland, Atmos. Environ., 38, 4035-4044, 2004.

Takegawa, N., Miyakawa, T., Kondo, Y., Blake, D. R., Kanaya, Y., Koike, M., Fukuda, M., Komazaki, Y., Miyazaki, Y., Shi- mono, A., and Takeuchi, T.: Evolution of submicron organic aerosol in polluted air exported from Tokyo, Geophys. Res. Lett., 33, L15814, doi:10.1029/2006GL025815, 2006.

Tsigaridis, K. and Kanakidou, M.: Global modelling of secondary organic aerosol in the troposphere: a sensitivity analysis, Atmos. Chem. Phys., 3, 1849-1869, doi:10.5194/acp-3-1849-2003, 2003.

Tsigaridis, K. and Kanakidou, M.: Secondary organic aerosol importance in the future atmosphere, Atmos. Environ., 41, 46824692, 2007.

Tsigaridis, K., Lathiére, J., Kanakidou, M., and Hauglustaine, D. A.: Naturally driven variability in the global secondary organic aerosol over a decade, Atmos. Chem. Phys., 5, 1891-1904, doi:10.5194/acp-5-1891-2005, 2005.

Tuch, T. M., Haudek, A., Müller, T., Nowak, A., Wex, H., and Wiedensohler, A.: Design and performance of an automatic regenerating adsorption aerosol dryer for continuous operation at monitoring sites, Atmos. Meas. Tech., 2, 417-422, doi:10.5194/amt-2-417-2009, 2009.

Volkamer, R., Jimenez, J. L., San Martini, F., Dzepina, K., Zhang, Q., Salcedo, D., Molina, L. T., Worsnop, D. R., and Molina, M. J.: Secondary organic aerosol formation from anthropogenic air pollution: Rapid and higher than expected, Geophys. Res. Lett., 33, L17811, doi:10.1029/2006GL026899, 2006.

Volkamer, R., Martini, F. S., Molina, L. T., Salcedo, D., Jimenez, J. L., and Molina, M. J.: A missing sink for gas-phase glyoxal in Mexico City: Formation of secondary organic aerosol, Geophys. Res. Lett., 34, L19807, doi:10.1029/2007GL030752, 2007.

Vrekoussis, M., Wittrock, F., Richter, A., and Burrows, J. P.: Temporal and spatial variability of glyoxal as observed from space, Atmos. Chem. Phys., 9, 4485-4504, doi:10.5194/acp-9-44852009, 2009.

Wehner, B., Philippin, S., and Wiedensohler, A.: Design and calibration of a thermodenuder with an improved heating unit to measure the size-dependent volatile fraction of aerosol particles, J. Aerosol Sci., 33, 1087-1093, 2002.

Zhang, Q., Worsnop, D. R., Canagaratna, M. R., and Jimenez, J. L.: Hydrocarbon-like and oxygenated organic aerosols in Pittsburgh: insights into sources and processes of organic aerosols, Atmos. Chem. Phys., 5, 3289-3311, doi:10.5194/acp-5-32892005, 2005

Zhang, Q., Jimenez, J. L., Canagaratna, M. R., Allan, J. D., Coe, H., Ulbrich, I., Alfarra, M. R., Takami, A., Middlebrook, A. M., Sun, Y. L., Dzepina, K., Dunlea, E., Docherty, K., DeCarlo, P. F., Salcedo, D., Onasch, T., Jayne, J. T., Miyoshi, T., Shimono, A., Hatakeyama, S., Takegawa, N., Kondo, Y., Schneider, J., Drewnick, F., Borrmann, S., Weimer, S., Demerjian, K., Williams, P., Bower, K., Bahreini, R., Cottrell, L., Griffin, R. J., Rautiainen, J., Sun, J. Y., Zhang, Y. M., and Worsnop, D. R.: Ubiquity and dominance of oxygenated species in organic aerosols in anthropogenically-influenced Northern Hemisphere midlatitudes, Geophys. Res. Lett., 34, L13801, doi:10.1029/2007GL029979, 2007.

Zuidema, P., Baker, B., Han, Y., Intrieri, J., Key, J., Lawson, P., Matrosov, S., Shupe, M., Stone, R., and Uttal, T.: An Arctic springtime mixed-phase cloudy boundary layer observed during SHEBA, J. Atmos. Sci., 62, 160-176, 2005. 